NBER WORKING PAPER SERIES

\title{
THE ROLE OF LABOR MARKET CHANGES IN THE SLOWDOWN OF EUROPEAN PRODUCTIVITY GROWTH
}

\author{
Ian Dew-Becker \\ Robert J. Gordon \\ Working Paper 13840 \\ http://www.nber.org/papers/w13840
NATIONAL BUREAU OF ECONOMIC RESEARCH
1050 Massachusetts Avenue
Cambridge, MA 02138
March 2008

Thanks to Bobby Krenn for superb research assistance, including his authorship of the Data Appendix. We are grateful to Bart van Ark, Susanto Basu, Nick Bloom, Allan Drazen, Richard Freeman, Greg Mankiw, Bill Nordhaus, Barbara Petrongolo, and Charles Wyplosz for their perceptive comments on earlier versions and to Andrea Bassanini, Romain Duval, Magnus Henrekson, and Guido Schwerdt for providing data. The views expressed herein are those of the author(s) and do not necessarily reflect the views of the National Bureau of Economic Research.

NBER working papers are circulated for discussion and comment purposes. They have not been peerreviewed or been subject to the review by the NBER Board of Directors that accompanies official NBER publications.

(C) 2008 by Ian Dew-Becker and Robert J. Gordon. All rights reserved. Short sections of text, not to exceed two paragraphs, may be quoted without explicit permission provided that full credit, including (C) notice, is given to the source. 
The Role of Labor Market Changes in the Slowdown of European Productivity Growth Ian Dew-Becker and Robert J. Gordon

NBER Working Paper No. 13840

March 2008

JEL No. E0,E23,E24,E60,J20,J21,J23

\begin{abstract}
$\underline{\text { ABSTRACT }}$
Throughout the postwar era until 1995 labor productivity grew faster in Europe than in the United States. Since 1995, productivity growth in the EU-15 has slowed while that in the United States has accelerated. But Europe's productivity growth slowdown was largely offset by faster growth in employment per capita, leaving little difference in growth of output per capita between the EU and US going back to 1980. This paper is about the strong negative tradeoff between productivity and employment growth within Europe. We document this tradeoff in the raw data, in regressions that control for the two-way causation between productivity and employment growth, and we show that there is a robust negative correlation between productivity and employment growth across countries and time. Our primary explanatory variables to explain both the revival of EU employment growth and the slowdown in productivity growth include six policy and institutional variables. We find that several of these variables have significant negative effects on employment per capita, both before and after 1995 . We also find a significant time effect, that the increase in European employment per capita increased after 1995 for reasons that go beyond our six explanatory variables, and we link this time effect to a secular increase in the labor-force participation of women, particularly in southern European countries. We conclude by suggesting that evaluations of alternative policy reforms in Europe should take into account any offsetting effects on employment and productivity by examining the ultimate impact on changes in income per capita.
\end{abstract}

Ian Dew-Becker

Department of Economics

Harvard University

Cambridge, MA 02138

idew@fas.harvard.edu

Robert J. Gordon

Department of Economics

Northwestern University

Evanston, IL 60208-2600

and NBER, and CEPR

rjg@northwestern.edu 


\section{INTRODUCTION}

Throughout the postwar era until 1995 labor productivity grew faster in Europe than in the United States. But since 1995, productivity growth in the EU-15 has slowed while that in the United States has accelerated. What caused this reversal? In principle one could imagine any number of causes, including a spontaneous acceleration in totalfactor productivity (TFP) growth in the U.S., a spontaneous deceleration of TFP growth in Europe, a change in labor-market policies and institutions in Europe that made labor both cheaper and less productive, a change in the level of investment in Europe, or any combination of these.

The starting point for the paper is the observation that after 1995, just as Europe's labor productivity growth slowed down relative to the US, its relative growth in hours worked per capita surged. Moreover, the countries within Europe that had the largest decelerations in productivity growth also had the largest increases in hours. As a result, the growth of European output per capita has fallen behind that of the US by a much smaller margin than its shortfall in the growth of labor productivity. Are the simultaneous turnarounds of productivity and hours per capita in opposite directions independent or related events, and if related in which direction does the causation run and what were the underlying causes? Is there a tradeoff between growth in hours and productivity, and what are the implications for policy? ${ }^{1}$

While we begin with contrasts between the US and EU-15, most of this paper is about heterogeneity within the EU-15. To facilitate generalizations about heterogeneity within Europe, we group European countries into the same geographical sub-aggregates as in Boeri et al. (2005), namely the Nordic, Anglo-Saxon, Continental, and Mediterranean countries. ${ }^{2}$ We pay particular attention to the contrast between the Mediterranean group and the other three groups, because the slowdown in productivity growth and revival of growth in hours per capita has been particularly pronounced in the two largest Mediterranean countries, Italy and Spain. The average population shares of the four groups over 1980-2004 were 5 percent for the Nordic group, 17 percent for the Anglo-Saxon group, 49 percent for the Continental group, and 29 percent for the Mediterranean group.

Our first empirical task is to describe the behavior of the leading policy and institutional variables that have been identified as relevant in the past literature on the pre-1995 decline in European hours per capita relative to the US. Our list of policy and

\footnotetext{
${ }^{1}$ The phrase "tradeoff" to describe the offsetting effects of labor supply shifts on productivity and employment may originate in Gordon (1997) and was implicit in Blanchard (1997).

2The only difference is that we label their "Other Europe" group as "Continental" and we group Ireland with the UK in the "Anglo-Saxon" group rather than in the "Other Europe" group as they do.
} 
institutional variables includes four policy variables - the labor tax wedge, the average replacement rate of unemployment insurance, and indices of employment protection legislation and product market regulation. Also included are two institutional variables describing outcomes rather than policies themselves, trade union density and an index of "high corporatism."

We examine changes in these policy/institutional variables over the time period between 1978 and 2003 and find that the turnaround from making labor more expensive to less expensive occurred with a different time path for each variable. This difference in the time path of the policy/institutional variables provides some caution to the easy verdict that everything - policy, institutions, and outcomes - all turned around simultaneously after 1995. We attribute the policy turnaround in the policy/institutional variables to two major sets of impetus to change the EU policy framework, the 1994 OECD Jobs Strategy and the 2000 Lisbon Agenda.

Next we ask is whether there is any systematic relationship between these sources of lower post-1995 labor costs and the subsequent post-1995 upsurge in European employment per capita. Before 1995, Europe could have been described as making labor more expensive, driving its labor market northwest along the labor demand curve with an accompanying decline in employment and increase in productivity. Starting at different dates for different policies, Europe began the process of shifting to the southeast, toward higher employment per capita but lower average productivity per hour.

Standard economic theory treats this southeast movement as a temporary phenomenon that occurs during a short period while the labor demand curve is held fixed. Soon dynamic responses should emerge that begin to restore the now-reduced ratio of capital to labor input toward its initial level. However, we find that this stimulus from higher employment to capital growth has not happened yet in most European countries; growth in capital per capita fell substantially from 2000 to 2004 for most European countries and regions. Thus, while our paper quantifies only the immediate static response of labor supply shifts on labor productivity, we find that there has been thus far no dynamic medium-term turnaround either in the growth rates of productivity or in capital per capita.

Our results need to be highly qualified. Policy and institutional variables do not explain all or even most of the post-1995 upsurge in European employment per capita. Much of the post-1995 employment increase has occurred for females, not males, and we interpret this not as a result of specific policy interventions but rather as a shift in culture and social norms toward a greater acceptance of females in the labor force, especially in Southern Europe. 
We distill a large European literature on the adverse effects of policies and institutions in dampening European employment per capita and raising labor productivity before 1995 and in reversing this process after after 1995. ${ }^{3}$ We develop regression models building on the best recent research to identify which policies and institutions changed and how much of the employment turnaround can be explained by these models. The size of our dataset - 23 years of data for 14 countries - gives us substantial power for identifying the relevant effects. Our paper is also unique in developing post-1995 simulations that quantify the effect of the policy and institutional variables on both employment per capita and productivity growth. ${ }^{4}$

The paper then proceeds to the relationship between employment and productivity. We develop an explicit econometric model that attempts to explain changes in labor productivity growth as a function of the turnaround in employment per capita. This model uses standard statistical procedures to eliminate the feedback from productivity growth to employment growth and allows us to measure the feedback from policy changes in explaining slower productivity growth after 1995.

Our results do not explain the majority of the post-1995 productivity turnaround in Europe. Rather, our focus is on identifying as precisely as possible the magnitude of the effects of policy on employment and productivity growth. We find that there is a strong and robust negative correlation between the growth of labor productivity and employment per capita across the EU-15. Last, we study the complete effects of policy changes output per capita.

Our story of declining European productivity growth emerges with multiple dimensions, including the impetus from changes in policies and institutions, and from other possible independent causes of employment growth, particularly the increasing role of female employment in the Mediterranean countries due to a combination of changes in social norms, the innovation of temporary employment contracts, and the role of immigration.

\footnotetext{
${ }^{3}$ Two important books on the European reform agenda are Baily and Kirkegaard (2004) and Alesina and Giavazzi (2006). Background on the 1994 OECD jobs strategy is given in OECD (2006, p. 24) and on the Lisbon agenda in Pissarides (2005, pp. 9-10).

${ }^{4}$ Even some of the most recent papers in this literature, e.g., Ohanian, Raffo, and Rogerson (2007), carry out analyses that focus on pre-1995 relationships without any attempt to test their pre-1995 hypotheses on post-1995 data.
} 


\section{DATA ON THE TWIN TURNAROUNDS}

\subsection{The Opposite Movements of Growth in Labor Productivity and Hours per Capita}

The story of the joint post-1995 turnaround in productivity and hours per capita is best told in Figure 1. Figure 1 plots our three core variables, labor productivity or output per hour $(\mathrm{Y} / \mathrm{H})$, versus hours per capita $(\mathrm{H} / \mathrm{N})$, and their product (output per capita, or $\mathrm{Y} / \mathrm{N}$ ), in a form that smooths the annual year-to-year wiggles of the data into long-run trends. ${ }^{5}$ We express hours and output on a per-capita basis, which partly levels the playing field due to the 0.7 percent per annum slower rate of population growth in the EU than in the US. ${ }^{6}$

The upper frame of Figure 1 exhibits the growth trends of EU and US output per hour since 1970 in the total economy (not the more frequently cited private business sector). The EU growth trend uniformly falls from about 5 to 1 percent per year, with a brief hiatus in the decline between 1988 and 1996. The US growth trend declined in the 1970s to a trough in 1981, then exhibited a modest recovery in the early 1980s and a much more significant revival after 1996. The difference between the EU and US growth trends changed from +2.2 percentage points in 1970 to -0.6 percentage points in 2006 .

The bottom frame of Figure 1 expresses growth in both output and hours per capita. The graph shows that the US trend growth in hours per capita was positive in most years until 2000, but negative from 2000 to 2005. In contrast, trend growth in Europe's hours per capita was strongly negative from 1970 to 1995, with a brief interruption in 1986-89. This negative trend reversed itself over the past decade, recording a positive trend growth rate of hours per capita in each year after 1995.

When $\mathrm{Y} / \mathrm{H}$ is multiplied by $\mathrm{H} / \mathrm{N}$, the divergent trend growth rates of productivity and hours per capita imply a surprisingly small EU-US difference in the growth rate of output per capita $(\mathrm{Y} / \mathrm{N})$. While Europe did show faster growth in the early 1970s, since then there has been a tie game, with average trend growth rates over 1975-2006 of 1.92 percent per year for the EU and 1.97 percent for the US. The problem is that Europe has failed to catch up to the US level of output per capita since 1975, with the EU-US ratio of output per capita roughly fixed at around 70 percent of the US level.

\footnotetext{
${ }^{5}$ The trends are created by a Hodrick-Prescott filter applied to annual data with a smoothing parameter of 12.5. The US trends are based on taking the annual average of trends fitted to quarterly data through 2007Q2, in order to highlight the 2004-06 downturn in US productivity growth.

${ }^{6}$ The difference between EU-15 and US population growth differs by concept and data source. With GGDC data EU-15 growth in total population grew 0.7 percent slower than in the US over 1970-2006. With OECD data the difference for total population was 0.54 percent and for population aged 15 and over was 0.53 percent.
} 
Growth of hours per capita is equal by definition to the growth of hours per employee $(\mathrm{H} / \mathrm{E})$ plus the growth of employees per capita $(\mathrm{E} / \mathrm{N})$. We choose in this paper to focus our analysis on the European turnaround in E/N. As shown in Figure 2, the post-1995 turnaround in $\mathrm{E} / \mathrm{N}$ is much more dramatic than in $\mathrm{H} / \mathrm{N}$. For the rest of this paper, we will use the metric of $\mathrm{E} / \mathrm{N}$ to summarize the European post-1995 turnaround.

Figure 1 raises an important question relevant to the interpretation of this paper. We are intrigued by the joint turnaround in opposite directions after 1995 between the US and EU-15 in the growth rates of employment per capita and in labor productivity. But clearly this turnaround-tradeoff story is not adequate to characterize the entire post1970 period plotted in Figure 1, where in the top frame the growth of labor productivity slowed much more between 1970 and 1980 and with no apparent corollary of rapid growth in hours or employment per capita. We view the story of declining productivity growth in the 1970s in both the US and EU-15 as outside of the scope of this paper. The focus and regression analysis of this paper concentrates on the turnaround in the behavior of both productivity and employment growth between the periods 1980-95 as contrasted to the period 1995 until 2003. ${ }^{7}$

\subsection{The Turnaround by Country and EU Country Group}

Table 1 summarizes the 1970-95 and 1995-2006 growth rates of $\mathrm{Y} / \mathrm{H}, \mathrm{H} / \mathrm{N}$, and $\mathrm{Y} / \mathrm{N}$ for the US, the EU-15, each EU country, our four EU country groups, and for the EU-15 excluding the Mediterranean countries. We focus here primarily on the turnarounds, that is, the difference between the 1995-2006 and 1970-95 growth rates for each of the three variables. The EU-US turnaround difference is -2.20 percentage points for $\mathrm{Y} / \mathrm{H}$, +1.99 points for $\mathrm{H} / \mathrm{N}$, and a mere -0.19 points for $\mathrm{Y} / \mathrm{N}$. These numbers are not listed explicitly in Table 1; they are calculated by taking the EU line and subtracting the US line in the column labeled "difference."

The role of the Mediterranean countries is shown by a separate "EU-15xMed" aggregate that excludes the three Mediterranean countries. The negative $\mathrm{Y} / \mathrm{H}$ turnaround when the EUxMed countries are compared with the row for the US becomes smaller from -2.20 points to -1.65 , the $\mathrm{H} / \mathrm{N}$ turnaround becomes smaller from +1.99 to +1.50 points, and the $\mathrm{Y} / \mathrm{N}$ turnaround becomes smaller from -0.19 to -0.15 points. Thus, while the Mediterranean countries contribute disproportionately to the post-1995 turnarounds in $\mathrm{Y} / \mathrm{H}$ and $\mathrm{H} / \mathrm{N}$, still a substantial turnaround in both productivity and employment growth remains in the rest of the EU-15. The negative correlation between growth in $\mathrm{H} / \mathrm{N}$ and $\mathrm{Y} / \mathrm{H}$ remains intact when the Mediterranean countries are excluded, and this is an important fact that is replicated in our subsequent econometric analysis.

\footnotetext{
7 We are grateful to our discussant Allan Drazen for pointing out that the data for the 1970s and 1980s does not exhibit any tradeoff.
} 
An important development in Europe since 1995 has been an increase in heterogeneity across countries. The bottom line in Table 1 shows that there has been an increase in the standard deviation across EU countries of all three variables, with a doubling in the standard deviation for $\mathrm{H} / \mathrm{N}$ and $\mathrm{Y} / \mathrm{N}$. With only a few exceptions, pre1995 growth in $\mathrm{Y} / \mathrm{N}$ was in the range of two to three percent, but after 1995 the range was from a low of 1.18 percent for Italy to a high of 6.17 percent for Ireland.

\subsection{Labor and Capital Ratios and Total Factor Productivity}

We now bring together data on countries including the US, the EU, and the four EU country groups, and compare the turnaround in $\mathrm{Y} / \mathrm{H}$ and $\mathrm{E} / \mathrm{N}$ with other components of growth accounting, namely the growth of hours per employee $(\mathrm{H} / \mathrm{E})$, in capital input per hour $(\mathrm{K} / \mathrm{H})$, capital deepening (the income share of capital times growth in $\mathrm{K} / \mathrm{H}$ ), and growth in total factor productivity (TFP). The numbers on the $\mathrm{Y} / \mathrm{H}$ and E/N post-1995 turnarounds are slightly different in Figure 3 and Table 2, which applies to 1980-2004, than in Table 1 that covers the longer period 1970-2006. This difference in dates is due to data availability regarding capital and TFP.

Figure 3 examines data on the trend growth rate in capital per hour $(\mathrm{K} / \mathrm{H})$ and in total factor productivity (TFP). The time path of EU growth in $\mathrm{K} / \mathrm{H}$ roughly parallels that of $\mathrm{Y} / \mathrm{H}$, with respective 1980-2004 decelerations between 5 and 2 percent annual growth for $\mathrm{K} / \mathrm{H}$ versus between 3 and 1 percent annual growth for $\mathrm{Y} / \mathrm{H}$. As shown in the bottom frame of Figure 3, the growth rate of TFP slowed steadily in the EU from 1983 to 2004 while that in the US accelerated in stages. The difference in TFP growth between the EU and US may be exaggerated by data discrepancies. ${ }^{8}$

We find several interesting facts in the bottom section of Table 2. For the US the turnarounds of $\mathrm{Y} / \mathrm{H}$ and TFP were identical and there was no turnaround in the capital deepening effect. This occurred as the result of slowdowns in the growth of capital per capita and hours per capita by the same amount, -0.49 percent. In the EU as a whole, the capital growth turnaround was about the same as the output growth turnaround, as shown by the small positive turnaround in the K/Y ratio at the bottom of the table. This implies that the negative turnaround in $\mathrm{K} / \mathrm{H}$ growth was almost as large as the positive turnaround in $\mathrm{H} / \mathrm{N}$ growth. As a result of this turnaround in the capital-deepening effect, the turnaround of TFP growth was -0.80 percentage points, slightly less than the -0.93 turnaround of $\mathrm{Y} / \mathrm{H}$ growth.

The four country groups display interesting differences. To what extent was

\footnotetext{
8 Standard growth accounting data for the US from US sources obtained from Kevin Stiroh suggests much slower K/H growth and much faster TFP growth in the 1980s than implied by the EU-KLEMS data displayed in Figure 3.
} 
growth in capital stimulated by growth in employment? An easy way to obtain this information from Table 2 is to compare the turnaround in capital per capita growth with that in employment per capita growth. The Nordic group had a modest negative turnaround in $\mathrm{Y} / \mathrm{H}$ growth and hardly any negative turnaround in TFP growth. This difference by definition is due to the fact that the negative turnaround in capital deepening was nearly twice as large as the TFP turnaround and thus accounts for most of the negative $\mathrm{Y} / \mathrm{H}$ turnaround. The negative turnaround in the $\mathrm{K} / \mathrm{H}$ ratio was entirely due to the increase in $\mathrm{H} / \mathrm{N}$, as the $\mathrm{K} / \mathrm{N}$ turnaround was close to zero. Thus our main impression is that the Nordic countries had a disappointing performance of investment despite a large turnaround in employment and a relatively strong productivity performance.

The Anglo-Saxon group is mainly driven by the UK. This group had the smallest $\mathrm{Y} / \mathrm{H}$ turnaround of the four European groups by a narrow margin, and the secondsmallest TFP turnaround. The slowdown in $\mathrm{K} / \mathrm{H}$ was much smaller than the increase in hours, due to a substantial increase in the growth rate of K/N. The Anglo-Saxon group thus has the best performance overall, with a modest slowdown in labor productivity and growth in capital per capita that was almost half the turnaround in employment per capita.

Not surprisingly, with its 49 percent population share in the EU-15, the performance of the Continental group was similar to the EU as a whole. The decline in both $\mathrm{Y} / \mathrm{H}$ and TFP growth was similar to the EU, while the sluggish revival of growth in $\mathrm{E} / \mathrm{N}$ was partly compensated for by an atypical turnaround toward positive growth in $\mathrm{H} / \mathrm{E}$. The slowdown in the capital deepening effect was dampened both by a modest increase in growth of $\mathrm{K} / \mathrm{N}$ and a small increase in the income share of capital. The modest positive turnaround in capital per capita growth was roughly one-third of the size of the turnaround in employment per capita growth.

As we have already seen, the Mediterranean group had the most noteworthy turnarounds for $\mathrm{Y} / \mathrm{H}, \mathrm{E} / \mathrm{N}, \mathrm{K} / \mathrm{H}$, capital deepening, and TFP. The slowdown in Mediterranean capital deepening was relatively modest, because the sharp negative turnaround in $\mathrm{K} / \mathrm{H}$ growth was partially offset by a sizeable increase in the income share of capital (from 28 to 34 percent). We note that the negative turnaround in $\mathrm{K} / \mathrm{H}$ growth was entirely due to faster growth in $\mathrm{E} / \mathrm{N}$, and that the turnaround in capital per capita growth was less than one-tenth of the turnaround in employment per capita. Thus a surprising finding is that the Mediterranean countries shared with the Nordic countries a disappointing performance of capital growth, while both the Anglo-Saxon and Continental groups display a positive response of capital per capita to more rapid growth in employment per capita.

The time-series dynamics of capital investment in the individual EU country groups is beyond the scope of this paper. We merely note a fact in the data, that the 
growth rate of capital investment was relatively weak in the Nordic and Mediterranean countries. This in turn helps to explain why the employment-productivity tradeoff, which would be assumed to be temporary, seems to have persisted at least through 2003. Something held back investment in Europe that would otherwise be expected to respond to the upsurge of employment growth.

\section{DEMOGRAPHIC VARIATION IN THE TURNAROUND OF EMPLOYMENT PER CAPITA}

In this section we look more closely at the turnaround in the growth of European employment per capita. We provide an analysis of the demographic components of the post-1995 increase in EU employment growth by decomposing employment into twelve age-sex groups. Did the post-1995 turnaround consist of increases across-the-board in each age-sex group or because the composition of employment shifted toward age-sex groups which already had relatively high employment per person? We can answer these questions with a simple shift-share analysis of 1985-95 and 1995-2005 E/N growth rates for the EU and our four EU country groups. Following Stiroh (2002), we calculate "employment" and "share" effects as,

$$
\begin{aligned}
& \text { employment_effect }=0.5\left(e n_{t}^{i}-e n_{t-n}^{i}\right)\left(s_{t}^{i}+s_{t-n}^{i}\right) \\
& \text { share_effect }=0.5\left(e n_{t}^{i}+e n_{t-n}^{i}\right)\left(s_{t}^{i}-s_{t-n}^{i}\right),
\end{aligned}
$$

where $e n^{i}$ is the employment to population ratio for group $i, s^{i}$ is the population share of group $i$, and $i$ indexes age-sex groups. By definition, the employment and share effects sum to the total change in employment between time periods $t-n$ and $t$ for a given country. The employment effect gives the contribution of the change in a group's employment to the total change in employment. The share effect calculates the effect of an increase in the group's population share. Since the sum of the share changes must be zero, the share effects will account for movements among groups with relatively high and low $\mathrm{E} / \mathrm{N}$ ratios, e.g., movements to low-participation groups like teenagers or the elderly from prime-age adults, or vice versa.

Figure 4 plots employment and share effects for our four country groups. Employment effects are shown in black and share effects are shown in grey. The top two panels display results for the Nordic and Anglo-Saxon country groups. The blackbar employment effects are generally small, although there was a substantial increase in male and female employment in both groups in the 55-64 age group. All Anglo-Saxon female groups from ages 64 down to 25 had substantial employment effects.

The Nordic and Anglo-Saxon groups also share a notable zig-zag in the share effects, with positive share effects for both men and women in the 55-64 age groups and 
negative share effects in the 25-34 age groups. This is likely the result of the aging of the population. It is also the result of post-1995 reforms which reduced "incentives to withdraw" and discouraged the early retirement of those in the 55-64 age groups (OECD, 2006, p. 133). It turns out that the share effects all cancel out, and their sum is only -0.01 . Intuitively, this is because the groups across which the population has been shifting all have similar employment rates. ${ }^{9}$

The bottom left quadrant of Figure 4 shows that employment effects in the Continental countries were less important than in the Nordic and Anglo-Saxon countries. But there were substantial share effects, particularly for the 25-34 age group.

The bottom right panel of figure 4 plots data for the Mediterranean countries. Again, there is the same effect of aging on the share effects, but the employment effects are substantially larger. 91 percent of the 6.6 percentage point increase in the employment rate in the Mediterranean countries is explained by employment effects, and the remainder by share effects. Since women started the period with much lower employment than men, we would expect most of the increase to be concentrated among women. As it turns out, 70 percent of the total Mediterranean employment increase can be explained by employment effects for women. Moreover, this increase is not just concentrated among the young; it is spread across all age groups except $65+$, and is focused on the prime working years.

The pattern of female employment explaining employment changes extends across three of our four country groups. In addition to the Mediterranean countries, female employment effects explain 68 and 59 percent of the total employment increases in the Nordic and Anglo-Saxon countries, respectively. In the Continental countries, female employment contributed a 1.3 percent increase in aggregate employment, but share effects and male employment canceled out essentially all of that. In the end, Figure 4 summarizes two important findings of this paper. First, we confirm the result that the European work force is aging, but aging has not yet substantially reduced employment in part because incentives for early retirement have been reduced.

The second result is that the majority of employment changes in Europe following 1995 can be explained by increases in prime-age female employment. The shift-share analysis helps us narrow down which variables are likely to be the most important, and these are the variables affecting women in their prime working years. ${ }^{10}$

\footnotetext{
${ }^{9}$ There is no reason that share effects have to sum to near zero. For example, if a country's employment rates by age stayed constant but the country suddenly went from being composed mainly of prime age workers to mainly retirees, the associated decline in employment would be entirely explained by share effects.

${ }^{10}$ For instance, both Allard and Lindert (2006) and Bassanini and Duval (2006) study the effects of retirement benefits. Our shift-share analysis shows that changes in employment rates of those
} 
The distinctly different behavior of the female from the male employment ratios in Figure 4 leads us now to develop regression equations explaining $\mathrm{E} / \mathrm{N}$ that distinguish between men and women.

\section{THE BEHAVIOR OF THE POLICY AND INSTITUTIONAL VARIABLES}

The basic question addressed in this paper is whether changes in policy and institutional variables in Europe, including cultural attitudes regarding female labor force participation, contributed to the post-1995 upsurge in European employment growth. In this section we first examine the time series behavior of the policy and institutional variables and then examine the background of these changes.

\subsection{Changes in the Policy and Institutional Variables}

Figure 5 shows the time series behavior for the six policy/institutional variables for our four country groups. The first of these is the tax wedge, defined as the total percentage rate of personal income and payroll taxation. This variable exhibits a sharp turnaround at exactly 1995 for all the groups except the continental countries. The largest decline was in the Anglo-Saxon countries, where taxes fell from 26 percent of income in 1995 to only 17 percent by 2002. The declines in Mediterranean and Nordic tax rates were 3 and 6 percentage points, respectively.

The OECD index of employment protection legislation (EPL) also exhibits a sharp turnaround at the same time; it was relatively flat until the early 1990's and then exhibited a substantial decline in the Nordic and Mediterranean countries. The index of product market regulation (PMR) declined through almost the entire period, though the decline began at varying times in the different country groups. Union density shows similar behavior by declining steadily over the entire period plotted in Figure 4 except for the Mediterranean countries.

Unemployment benefits as measured by the average replacement rate (ARR) displays the opposite trend as do the other variables. If anything, ARR rose during our sample. Overall the behavior of these policy/institutional variables does not support a simple story that these variables turned around in tandem after 1995 and provide the main explanation of the employment and productivity turnarounds illustrated in Figures 1 and 2 above. The most promising variables for this interpretation are the tax wedge, EPL, and to a lesser extent PMR.

around retirement age were not large enough to explain substantial amounts of variation in aggregate employment. 
It is important to note that the country group averages displayed in Figure 5 represent an expositional device that has no bearing on our subsequent regression analysis. Our regressions attempting to explain the behavior of growth in employment per capita and in labor productivity are based on data for 14 individual countries for each year, not the four country groups.

\subsection{Background of the Changes}

Why did policies move in the 1970s and 1980s in the direction that reduced employment per capita? There is a consensus view that this occurred because policies adopted to fight unemployment had adverse effects on employment per capita (see Nickell et al. 2005). To deal with the individual hardship caused by higher unemployment, governments increased the generosity and duration of unemployment benefits. To limit the increase in unemployment itself, they attempted to regulate layoffs through employment protection legislation (EPL). To spread the available jobs across the population, they resorted to legislation favoring early retirement and shorter hours of work, so-called "work sharing" (Alesina, Glaeser, and Sacerdote, 2006).

As shown in Figure 5, the policy and institutional variables turned around at different times in different countries, with the clearest post-1995 turnaround in the tax wedge in three of the four EU country groups. A catalyst for the post-1995 turnaround was the 1994 OECD Jobs Strategy. This landmark agenda had a major influence on EU policymakers to shift their focus from alleviating the impact of high unemployment to reforming labor markets with the aim of raising employment per capita. Five of the ten key recommendations of the 1994 OECD Jobs Strategy involved turning around several of the key policy variables that enter into our analysis of the growth rates of employment per capita and productivity. These included reforming EPL, PMR, and ARR (see OECD, 2006, p. 24).

The Lisbon Agenda of 2000 reinforced the change in emphasis toward raising the ratio of employment per capita, especially for females, by reducing the unemployment rate and particularly by raising the labor-force participation rate. Quantitative targets were set for the employment-population ratio of women in 2005 and 2010 (Pissarides et al. 2005).

Several policies were changed that are not included in our regression analysis. Unemployment benefits were reformed not only by reducing the unemployment benefits ratio (ARR), but also by reducing the duration of benefits. Another change that is difficult to quantify is the strictness with which eligibility for unemployment benefits was administered, so-called "gate-keeping mechanisms" (OECD, 2006, p. 62, 75).

Overall, it would appear that the turnaround in the policy and institutional variables was a very gradual process, reacting at first to high unemployment by 
adopting measures that made labor more expensive, but then recognizing after some lag the benefits of making labor cheaper. Given the long lags evident in this process, and the very different timing of the turnaround in the policy and institutional variables, we are not concerned that these variables are systematically endogenous to the time-series behavior of employment per capita or of labor productivity.

\section{THE RESPONSE OF EMPLOYMENT PER CAPITA TO POLICY AND INSTITUTIONAL CHANGES}

The point of departure for our study of the EU employment turnaround is a substantial literature that debates the sources of the postwar decline in the ratio of EU to US hours per capita - 48 percent (in logs) from 1960 to 1995. There is widespread agreement that Europe made labor more expensive, at least before 1995, but less on the ultimate causes. There is much less work on understanding how much of the post-1995 turnaround in $\mathrm{H} / \mathrm{N}$ can be linked to a reversal of the underlying policy and institutional variables.

\subsection{The Previous Literature on Changes in Hours per Capita and Employment per Capita}

Prescott (1994) is the best-known advocate of the view that the sharp decline in European hours per capita is entirely due to high labor taxes. Prescott establishes his result with theory and calibration methods, and a paper that interprets his results by Alesina, Glaeser, and Sacerdote (2006) calculates that Prescott's elasticity of hours per capita to a change in the tax wedge is -0.92 . The Alesina et al. paper argues that, because males have a small labor elasticity, the tax elasticity may be only as high as -0.40 to -0.45 .

Several papers, including Davis and Henrekson (2004), attempt to replace the assumed tax elasticity of Prescott with elasticities estimated from the data. They find a tax elasticity of -0.22 , but their results are qualified by using data only for four years between 1977 and 1995. A paper closely related to ours is Allard and Lindert (2006). Their aim is to sort through all of the exogenous policy variables that might have reduced European hours and employment, but, surprisingly, they do not notice the post-1995 turnaround in hours or in employment per capita. In the end the AllardLindert analysis is uni-dimensional. They pluck candidates to explain lower European hours growth or productivity growth, with no recognition that there may be a negative tradeoff between them. They also fail to recognize that there may be a two-way causation between productivity and employment changes. ${ }^{11}$

\footnotetext{
${ }^{11}$ Among other previous sources estimating regressions to explain changes in European labor input are Beaudry and Collard (2001), Blanchard and Wolfers (2000), and Pissarides et al. (2005). Ljungqvist and Sargent (2006) have joined the debate with Prescott by emphasizing the
} 


\subsection{Regression Equations Explaining Employment per Capita}

The most recent and convincing paper in this literature is from Bassanini and Duval of the OECD (2006), hereafter B-D, who explain movements in the unemployment rate and per-capita employment in a variety of econometric specifications. We incorporate their data developed at the OECD but provide a different set of regression equations that are used both to obtain coefficients on the effects of alternative policy and institutional variables. Unlike B-D and previous authors, we use the estimated coefficients to estimate counterfactual simulations. Did the post-1995 upsurge in employment per capita respond to changes in our set of variables, or was there an unexplained component?

Since we are asking different questions than B-D, we use a somewhat different specification than theirs. Whereas B-D studied the determinants of changes in employment per capita in 20 OECD countries, including the US, Canada, and Japan, our sample consists of the EU-15 minus Luxembourg. We also weight our regressions by population in order to provide the most appropriate results for discussing the EU, in contrast to their unweighted regressions that give the same importance to Luxembourg and the United States. The larger countries better represent the EU as a whole and should be treated as such in the regressions. ${ }^{12}$ Furthermore, in the interest of obtaining results that apply at the aggregate level, we run regressions using the total employment rate, not just broken down by age and gender.

Last, we run the regressions in growth rates, rather than levels, because we have found that the residuals in the levels regressions seem to follow a random walk. ${ }^{13}$ Our basic model posits that the level of employment is driven by the levels of the policy variables and the output gap. We then take the first difference of the entire equation so that the actual regression is of the growth rate of the employment rate $(E / N)$ on the growth rates of the policy variables and the change in the output gap. ${ }^{14}$

In addition to the important change from levels to logarithmic growth rates, there are several other technical details in our regressions that differ from B-D and make

disincentive role of the welfare state that is paid for by the tax wedge. A comprehensive list of such studies is presented in OECD (2006, p. 93), but this list applies only to studies in which the dependent variable is the unemployment rate, not $\mathrm{E} / \mathrm{N}$.

${ }^{12}$ Tables 4 and 5 below display results comparing identical specifications with and without population weights.

${ }^{13}$ This fact likely explains Bassanini and Duval's finding of R2's equal to 1.0.

${ }^{14}$ The final regressions are actually run with two-year changes of the policy variables expressed as an annual rate. This allows their effects to have up to a one year lag. The coefficients reported all correspond to the long run relationship between the levels of the variables and the level of the employment rate. 
them more appropriate for the questions that we ask in this paper. Our baseline results differ from those of B-D by including males and females from ages 15-64 rather than their 25-54, by eliminating splits (pre, post 1992) in country effects for Germany, Finland, and Sweden, and by further filling in some missing data in their data set so that our results cover 1979-2003 rather than their 1982-2003. ${ }^{15}$

\subsection{Employment Regressions Based on OECD Employment Data}

Table 3 presents our regression results for total employment per capita for both sexes and then separately for men and women. The data begin in 1979 and so the variables, expressed in the form of rates of change, begin in 1980 and extend through 2003. The observations are across all years and all the EU-15 countries excluding Luxembourg. Thus we have more than 300 observations. Our device of summarizing the four EU country groups in part 2 of this paper has no impact on the regression analysis. The observations that we examine here are for individual countries, year-byyear, and the country aggregates are not included in any way.

The explanatory variables are arranged in groups. The first four rows, corresponding to the first four frames of Figure 5, exhibit the four policy variables, that is, the tax wedge (TW), employment protection legislation (EPL), product market regulation (PMR), and the average replacement rate of unemployment insurance (ARR). The next two explanatory variables are better described as "institutional" rather than "policy," namely union density and a dummy variable for "high corporatism." The first six rows of explanatory variables would be expected to have negative coefficients, as they represent factors that make labor more expensive and thus to reduce E/N. The next explanatory variable is the change in the output gap, a measure of the influence on employment of the business cycle. Finally, we also include a dummy variable equal to 1.0 after 1995 and 0.0 before 1995, to detect changes in the trend that are not explained by the policy and institutional variables. ${ }^{16}$

The most important finding from Table 3 is that all of the policy/institutional variables listed on the first six lines have significant effects with the expected negative sign with the exception of the EPL and PMR regulatory variables. The change in the output gap has the expected positive coefficient at a high level of significance, and the post-1995 time dummy has a significant positive coefficient representing a separate cause of faster growth rate of $\mathrm{E} / \mathrm{N}$ in Europe for men, women, and the combined both-

\footnotetext{
${ }^{15}$ Details are in the data appendix.

${ }^{16}$ To call attention again to important differences between our research and that in one of the more recently published paper on this topic (Ohanian, Raffo, and Rogerson, 2007), we include all policy/institutional variables together whereas they introduce them only as one-by-one alternatives rather than together, they do not include any variable like the output gap to control for the business cycle, and they do not consider the possible issue of a time-shift effect after 1995.
} 
sex results that goes beyond the explanation available from the quantitative policy variables.

The negative coefficients for the change in the tax wedge are highly significant. Our baseline coefficient for both sexes of -0.28 is lower than that favored by Alesina et al. (2006) in the range of -0.40 to -0.45 but higher than the -0.22 coefficient obtained by Davis-Henrekson on the basis of a much smaller data set than ours. For the results divided by sex, our tax wedge coefficient for men of -0.21 is not too far below the B-D coefficient of -0.30 , and our female tax-wedge coefficient of -0.37 not too far below the B$\mathrm{D}$ coefficient of -0.50 . Given the different samples, time periods, and our shift from levels to rates of change, differences of this magnitude are to be expected. The important point to recognize is that changes in the tax wedge are highly significant determinants of changes in employment per capita.

How much of the change after 1995 do these employment regressions actually explain? This is perhaps the first paper to ask that question. We have a set of explanatory variables and regression coefficients for the entire 1980-2003 period. Figure 6 takes the regression results from Table 3 and converts those changes in the dependent and explanatory variables into levels.

We can use these 1980-2003 regression coefficients to decompose the post-1995 behavior of employment per capita based on three assumptions which correspond to the three lines in Figure 6, in which the top frame reports results for males and the bottom frame reports the results for females. The "predicted" line plots the prediction of the econometric equations assuming the actual values of the policy/institutional variables and the actual values of the time dummy coefficients. The "Fixed Policy" line sets the six policy/institutional variables at their 1995 values and calculates how much difference would have been made to employment if those six variables had maintained their actual post-1995 values rather than their fixed counterfactual 1995 value. Then the "no dummy" line calculates an alternative results which eliminate the effect of the time dummy on the results.

The regressions are run with the growth rate of $\mathrm{E} / \mathrm{N}$ as the dependent variable. It is quite possible for this growth rate to be negative, as it was for men as shown in the top frame of Figure 6. The graphs in the top and bottom frames of Figure 6 convert these growth rates into levels. For both males and females, the growth rate of employment would have been much lower without the help of the time dummies.

\subsection{Interpretation of the Time Effects}

This section provides an interpretation of the time effects estimated in Table 3. Why might the growth rate of $\mathrm{E} / \mathrm{N}$ have turned around after 1995 for reasons not related to our six policy and institutional variables? The 1994 OECD Jobs Strategy and the 2000 
Lisbon Agenda (discussed above in section 4.2) focus their reform efforts on a primary goal of boosting the ratio of employment per member of the working population $(\mathrm{E} / \mathrm{N})$, particularly for women. In 1978 the female $\mathrm{E} / \mathrm{N}$ ratio ranged between 54 percent in Sweden and 25 percent in Spain, with an EU-15 average of 35 percent. By 2003 this ratio had remained the same for Sweden at 54 percent but had risen for Spain to 36 percent and for the EU-15 to 43 percent. The quantitative goals of the Lisbon reforms were very ambitious, to raise the EU average to 57 percent by 2005 and 60 percent by 2010 (Pissarides et al. 2005, pp. 9-10). We observe in Figures 4 and 6 a substantial increase in employment per capita for women, particularly in the Mediterranean countries. What caused the ongoing convergence in employment per capita for women compared to men, and for Mediterranean women in particular?

Our basic regression results in the third column of Table 3 imply that there was a substantial shift over time captured in the largely positive country fixed effects for females plus the added impact of the post-1995 time effect. For Spanish females, there was a country-specific positive growth rate of female employment per capita of 1.62 percent between 1980 and 1995 period, rising by 0.66 percent to 2.28 percent subsequently. We need to determine the causes of this substantial shift in the actual employment rate of Spanish women from 25 percent in 1978 to 36 percent in 2003, a total increase of 44 percent, or an annual log growth rate of 1.46 percent.

Basic explanations for the movement of women into the labor force begin with the literature on the United States where female participation surged between 1965 and 1985 (as summarized in Pissarides et al. 2005, pp. 26-28). The invention and diffusion of consumer durables freed up the time of women previously devoted to household drudgery, and the arrival of contraceptives provided a chance for women to gain control over the timing of pregnancies and work effort. This effect has been christened by Galor and Weil (1995) as "female-biased technological change."

"Persistence" and "social norms" are often discussed in this literature. Once mothers entered the labor force, it became more acceptable for daughters and their sisters to enter. Authors suggest that there was simultaneously a new acceptance of market employment by potential female employees, and a change by employers in their willingness to accept that new employees would be females.

Previous research (including Bertola et al. 2002 and Davis and Henrekson 2004) notes the relatively small size of the retail and service sectors in Europe compared to the United States, and this formerly deprived women of opportunities for flexible and parttime employment in these sectors. Reduction of product market regulations may have played some role in allowing women to enter the labor force, but that cannot explain the positive post-1995 dummies in our regressions since PMR is included as a regressor. 
An important recent innovation in European labor markets is temporary job contracts. These allow employees to be hired without the previous overhang of regulations against firing. These new types of contracts may explain the role of the positive time dummy variables in the regressions of Table 3, but they are part of the definition of the EPL variable and indeed the reduction of regulations preventing temporary employment contracts is the single biggest factor that caused the OECD's EPL index to decline after 1995 ((OECD, 2006, p. 95). The growth of temporary contracts was very important in contributing to the growth of E/N in Spain (Paramio and Zoffo, 2005).

In addition, increased immigration to countries like Spain (as examined by Heinz and Ward-Warmedinger 2005) may be an exogenous event helping to explain why the time dummy in Table 4 is positive. Bentolila et al. (2007) document that the percentage of foreign-born in the Spanish population increased from a mere one percent in 1991 to 11 percent in 2006 . These potential new members of the labor force may have been pulled into Spain by employment opportunities and could have contributed to the post1995 increase in the growth rate of employment in Spain.

\subsection{Employment Regressions Based on GGDC Employment Data}

We now turn to the primary objective of this paper, which is to relate the post1995 mutual positive turnaround in the growth rates of employment per capita (E/N) and the negative turnaround in in the growth rate of labor productivity $(\mathrm{Y} / \mathrm{H})$. Because the primary data relevant to our study of productivity comes from the Groningen Center (GGDC) rather than the OECD upon which we have previously relied for the decomposition of $\mathrm{E} / \mathrm{N}$ by sex, we now present regressions explaining changes in employment identical to those of Table 3 but now using a different data source for the dependent variable (the log growth rate of employment per capita). All the data on the explanatory variables are identical throughout the paper.

These regressions will be used as a first stage for the productivity regressions that are the centerpiece of our analysis. Our goal is to find good instruments for employment, i.e. variables that explain employment as well as possible but that have no independent effect on productivity.

Table 4 reports results from the employment regressions. Due to lack of data, these refer only to both sexes combined, in contrast to the results in Table 3 for the two sexes separately. As in Table 3, the observations are across all years from 1979 to 2003 and EU-15 countries, with exceptions noted in the data appendix. Column 1 reports results for a simple regression with country fixed effects. The coefficients on the tax wedge, PMR, ARR, union density, and the output gap are all significant and have the "correct" signs, i.e. higher levels of taxes and regulation lower the employment rate. We find no effects from EPL. This result holds through all of our specifications. The output 
gap has by far the most explanatory power for employment, with a t-statistic of nearly 11. Next most powerful are the tax wedge and union density. These two variables will be our most powerful instruments in the productivity regressions.

Column 2 of Table 4 adds a dummy equal to 1 following 1995 and 0 otherwise to account for a possible exogenous shift in the growth of the employment rate. The coefficient on this dummy is highly significant and indicates that average employment growth across Europe rose by nearly a full percentage point following 1995 (the accompanying box discusses possible reasons for this shift in employment growth after 1995). The other coefficients remain largely unchanged. The only notable differences are that the coefficients on ARR and union density rise somewhat.

Columns 3 and 4 present two important robustness tests for the model. ${ }^{17}$ In column 3 we drop the population weights. The results are nearly identical to column 2 . All of the changes in the coefficients are less than one standard error. EPL becomes marginally significant, but this result is unique to column 3 . In column 4 we add dummies for each year so that the model is fully saturated, i.e. there is a dummy for each country and each year. Our results remain essentially unchanged. The coefficient on the tax wedge declines somewhat, to only -0.15 , and the coefficient on corporatism declines to -1.59 , being significant at only the $10 \%$ level. We view the inclusion of the year-by-year time dummies as a robustness check, not a part of our basic results, and it is encouraging that this robustness check makes very little difference to our basic results.

Column 2 is our preferred specification and will be used as the first stage for instrumental variables regressions explaining the annual growth rate of labor productivity in section 6 . We have a number of candidate instruments: union density, ARR, high corporatism, the tax wedge, and the post-1995 dummy. The prime test for whether these instruments are valid is whether they have an independent effect on productivity, which we will examine below. We will also further discuss the intuition behind our identification. The post-1995 dummy in particular is somewhat questionable and will not be used in our primary regressions.

\footnotetext{
${ }^{17}$ In the appendix we include a table of extra robustness tests. When Spain or the Mediterranean countries are excluded, we find that the coefficient on the post-1995 dummy falls from 0.9 to 0.7 . When the US is included with its own post-1995 dummy, the coefficient on that variable is -0.38 , indicating an unexplained decline in US employment growth, primarily due to a substantial decline in the US labor force participation rate of youth that has been widely noted and discussed.
} 


\section{THE IMPACT OF POLICY AND EMPLOYMENT ON PRODUCTIVITY}

We now combine all the aspects of growth in employment per capita and in output per hour in the European economy since the late 1970s in order to estimate the effect of employment growth on productivity growth. As before, we focus on the turnaround after 1995.

Before presenting the empirical results, it is worth stopping to understand why there might be a causal relationship between productivity and employment. Standard models of production posit that labor productivity is an increasing function of the quantity of capital supplied per worker. ${ }^{18}$ If the capital stock is fixed in the short-run, that is, if any response of investment to changes in labor market conditions takes time, measured as several years. When employment rises, the capital to labor ratio falls, driving labor productivity down.

If investment responds quickly and positively to changes in employment, then the tradeoff between employment and productivity will be quantitatively small. Alternatively, if capital responds slowly or not at all, then the tradeoff will be long lived. In general, theory tells us to expect a response of investment, but this is unlikely to occur with sufficient speed to obscure the short-run productivity-employment tradeoff.

If employment increases but the new workers are on average less skilled than those who were already working, then we will also find a negative relationship between employment and productivity. The remainder of section 6 is devoted to quantifying this tradeoff. If it exists, it has important implications for policy choices.

\subsection{Reduced Form Regressions}

We attempt in this subsection to unite two separate but related strands of literature. The first is the work discussed in Section 5.1 and 5.2 that analyzes the determinants of employment. The second literature is the one that examines the relationship between productivity and employment. Layard, Nickell and Jackman (2005) in their first two chapters provide microeconomic foundations for the classic labor supply and demand framework. Subsequent researchers used various methods to quantify the short-run employment-productivity tradeoff; ${ }^{19}$ they were essentially

\footnotetext{
${ }_{18}$ We can consider a constant returns to scale production function $\mathrm{F}(\mathrm{K}, \mathrm{L})$. Constant returns implies that we can write $F$ in its so-called "intensive form" $F(K, L)=L \cdot F(K / L, 1)=L \cdot f(K / L)$. We then can write labor productivity as $Y / L=f(K / L)$, where $f$ is an increasing and concave function. ${ }_{19}$ Bourles and Cette, 2005, are the state of the art in this literature, but see also Beaudry and Collard, 2002; Beaudry, Collard, and Green, 2005; and McGuckin and van Ark, 2005, among others.
} 
tracing the labor demand curve. In this and the following sections, we merge these two strands of research, attempting fully to quantify the effects of policy choices on productivity and employment, and to begin to identify the mechanisms through which these choices act. As indicated before in the introduction, our analysis is static and short-run. It does not trace through the full dynamic response of productivity to employment, because we cannot find that so far Europe has begun to experience the dynamic response predicted by theory.

The structural model in the previous section provided two reasons why an increase in employment can create a short-run negative relationship between employment and productivity - that is, a downward sloping short-run labor demand curve. When employment rises, the capital to labor ratio necessarily falls since investment cannot respond instantaneously. Secondly, when employment rises the new workers tend to be less skilled and less experienced. Following an increase in employment, it takes time for the capital stock to grow enough so that the capital to labor ratio returns to its initial level and for average experience to rise.

Following the work of past authors, we begin with a simple regression of productivity growth on growth in employment per capita, the results of which are reported in Table 5. ${ }^{20}$ As in section 5, the model underlying this regression is one in which the level of productivity is affected by the levels of employment and the policy variables. We take first differences before running the regression.

Of the policy variables, EPL and ARR both have significant effects on productivity after controlling for employment, which rules them out as valid instruments. Both of their coefficients are positive, a result that is robust across all of our specifications. This result is surprising because we usually think of government regulation as interfering with the market and lowering productivity. The result that unemployment insurance could raise productivity is not original to this paper, however. Acemoglu and Shimer $(1999,2000)$ develop a model of employment with matching in which higher unemployment benefits give firms incentives to create better matches and hence higher productivity. Similarly, EPL, by making employer-employee relationships last longer, could increase job-specific human capital. ${ }^{21}$

Past authors, most notably McGuckin and van Ark (2005), have tested whether there is a long run effect of employment on productivity. That is, they regress multiyear averages of productivity growth on the same averages of employment growth. An alternative to this method is to regress productivity on both the current and lagged values of employment growth. If the long run impact of employment on the level of productivity is zero, then the initial negative coefficients of employment should be

${ }^{20}$ As in the employment regressions above, the sample is the EU-15 excluding Luxembourg for 1980-2003 and observations are weighted by population except as noted otherwise.

${ }^{21}$ Barbara Petrongolo initially pointed this out to us. 
followed by offsetting positive coefficients on the lags of employment growth. When we add lagged values of employment to the productivity regressions, the results are entirely unchanged. In other words, we find that the short-run effect of employment seems to be permanent. ${ }^{22}$ This result is consistent with our finding in Figure 3 and Table 2 above that growth in capital slowed in Europe while growth of employment was increasing.

We suggest three speculative explanations for a minimal response of investment to employment growth. First, new inexperienced entrants to the labor force could be employed in retail, trade, and service establishments that were previously underutilized. If PMR previously required that shops closed in evenings and on Sundays, and PMR was loosened to allow longer hours, then some of the new employees might have been employed with the same capital stock that existed before. We think this is an important reason why capital investment did not respond to the increase of employment, especially in the trade and service sectors.

The second explanation relies on the fact that marginal workers tend to be the least skilled and have the least income. Workers with low incomes likely have relatively high marginal propensities to consume out of income. In this case, the income that goes to the new entrants to the labor force may not drive up saving or investment.

A third more speculative explanation for the failure of investment to respond to higher EU E/N concerns the cross-border aspect of capital investment within Europe. If the Spanish E/N increases because of an inflow of previously at-home females and of immigrants from Morocco, does that trigger an inflow of investment to Spain from other countries? It is possible that this provides an incentive to domestic and foreign investment firms to invest more in the Spanish retail and service sectors, but this response time may be very long, at least longer than the time horizon of this paper.

\subsection{Identifying Causation by Using Instrumental Variables}

Up to this point these regressions do not identify causation from employment growth to productivity growth, because the opposite direction of causation could create the same negative productivity-employment correlation. That is, the regression would not be identifying the slope of the short-run labor demand curve. ${ }^{23}$ For example, a

\footnotetext{
${ }^{22}$ We also ran regressions similar to those of van Ark and McGuckin with moving averages of employment growth, and our results remained unchanged.

${ }^{23}$ Theoretical work, e.g. Acemoglu and Shimer $(1999,2000)$ and Lagos $(2006)$, using matching models has shown that there may be more complex interactions than the simple supply-demand framework can describe. In the Acemoglu-Shimer model, unemployment benefits impact workers' decisions whether or not to accept job offers. Because workers are less motivated to accept a job offer when benefits rise, firms essentially choose a different production function that has higher output per hour worked. Policy only directly affects employment rates. Because labor
} 
classic technology shock, such as the internet revolution, could raise worker efficiency and productivity and lead to a decline in the demand for workers. ${ }^{24}$ It would change both productivity and employment growth, and therefore conventional OLS estimates would be inconsistent.

On the other hand, the classical Real Business Cycle (RBC) technology shock that causes an economic expansion, simultaneously raising employment and productivity, would go in the opposite direction as our results and hence does not present an identification problem. Past studies of the employment-productivity tradeoff have used various instrumental variables methods, but they have not included as rich a model of employment dynamics as we have developed previously in this paper. We therefore take advantage of the power of this model to predict employment.

Column 2 of Table 5 reports results from a two-stage least squares (2SLS) regression using the tax wedge as the instrument. The key identifying assumptions are that the tax wedge has no direct impact on productivity and that the effect of taxes on productivity is mediated by employment. Since taxes simply affect the labor supply decision, we see no reason why they should directly affect labor productivity. Moreover, since the tax wedge only drives labor supply decisions, presumably any effects on productivity must be driven by employment.

Table 4 shows that the tax wedge is a good predictor of employment changes, and table 5 shows that is has no effect on productivity after controlling for employment. ${ }^{25}$ We find a highly significant negative coefficient on employment growth but now somewhat smaller, -0.65 in column 2 as compared to -0.84 in column 1 . The standard error, however, is substantially larger, at 0.20 . Our estimated employmentproductivity tradeoff is nearly identical to that estimated by Bourles and Cette (2005), even though they also used a slightly different sample in terms of countries and years included and a substantially different set of instruments.

It is worth asking whether the tax wedge might be somehow caused by productivity, and if so, what the results would be. There are two opposing ways that taxes might be driven by productivity. First, governments might raise taxes when the budget is in deficit, and lower them when there is a surplus. In that case, we would expect to see taxes fall when labor productivity is high, and vice versa. This would induce a negative correlation between taxes and productivity. Since employment is negatively related to tax rates, this would imply a positive relationship between

supply falls, productivity rises. This is an interesting alternative mechanism for the productivityemployment tradeoff that we do not further explore here.

${ }^{24}$ See, e.g. Basu, Fernald and Kimball (2006).

${ }^{25}$ Our 2SLS regressions also pass the Sargan test for instrument validity. We can never the null hypothesis that our instruments are valid even at the 20 percent level. The regressions using alternative sets of exogenous instruments also pass this test. 
employment and productivity. A tax policy responding to fiscal balances would run against our results and hence does not present an identification problem.

In order for taxes to be an invalid instrument, they would need to be positively correlated with productivity. Suppose governments follow a Keynesian policy whereby they raise tax rates during booms, when productivity is high, and lower taxes during recessions when productivity is low. In that case, taxes would be positively correlated with productivity. Since employment is negatively correlated with the tax wedge, this would mean that we should find a spurious negative correlation between productivity and employment.

It is not possible in our model statistically to differentiate between these two stories about taxes. We therefore present a set of alternative identification strategies in the appendix. We drop the tax wedge and use only the high corporatism dummy and union density as instruments and find results nearly identical to those obtained using the tax wedge. The appendix also explores using alternative lag structures, dropping the output gap from the right hand side of the regression, and changing the sample of countries. In some specifications, the coefficient on employment is no longer statistically significant, but it is never less negative than -0.24 , and the point estimate is almost always more negative than -0.40 .

Moving back to our main results, the size of the coefficient we find on employment is surprisingly large. A coefficient of -0.64 on employment growth is larger than a simple Cobb-Douglas production function would predict. That model would tell us that we should expect the coefficient on employment to be equal to the capital share of income in the economy. We find a value of -0.64 that is roughly twice the typical onethird share of capital. This is evidence in support of the proposition that when employment rises, the new workers tend to have lower human capital, which could be embodied in education, acquired skills, or simply experience.

Column 3 adds the post-1995 dummy as an instrument. Identification with the dummy variable comes from regressing the average unexplained productivity change after 1995 on the average unexplained employment change. In other words, we are taking the entire employment residual as being exogenous. A motivation for this method would be that most of the change following 1995 was driven by social factors encouraging female employment such as those discussed above in section 5.4, or by policy variables not included in the regressions, rather than reverse causation from productivity to employment. The main advantage of making this assumption is that we cut the standard error on the employment coefficient in half, from 0.20 to 0.10 . The point estimate rises somewhat to -0.74 . This model, as all of our others, passes the (admittedly weak) Sargan test for instrument validity. Moreover, it is notable that in none of the regressions in table 5 or the appendix do we find a significant coefficient on the post- 
1995 dummy in the second stage. That said, in the interest of conservatism, the remainder of the results are identical to those in column 2.

In columns 4 to 6 , we take every variable that was significant in the employment regressions but not the productivity regressions and use them as instruments. The set includes the tax wedge, union density, and high corporatism. This instrument set gives us identification as powerful as in column 4 , but without the concerns about reverse causation. In this case, the coefficient on employment is still -0.65 , with a standard error of 0.11 .

Last, columns 5 and 6 add two robustness tests as in table 4 . In column 5, we drop the population weights. This causes the coefficient on PMR to become substantially larger, and marginally significant, and the coefficient on EPL to shrink somewhat. The coefficient on employment growth, however, remains unchanged. In column 6, we add year dummies. This could be motivated by the possibility that there are common technology shocks that affect labor productivity in every country in a given year. In this case, we find a somewhat larger standard error on the employment coefficient. The coefficient on EPL also declines somewhat, from 1.77 to 1.19. Looking at table 5 as a whole, what we are finding is that the negative relationship between employment and productivity is robust to a variety of different identification schemes and panel models. We never find a coefficient less negative than -0.60 . The positive effects of EPL and PMR are also robust across all the specifications.

Our results are somewhat in tension with those found by Nikoletti and Scarpetta (2003) and Allard and Lindert (2006). Nikoletti and Scarpetta find a negative relationship between PMR and TFP at the industry level. Allard and Lindert, in macro regressions similar to ours, report three specific results. They find that EPL and PMR both have negative impacts on productivity, and tax wedges have no net effect. Our regressions find near zero coefficients on all five variables except for PMR and EPL, which have positive coefficients. The fact that we include a broad set of controls in our regressions helps to explain our different results. Moreover, since we only use short lags of the policy variables, it is possible that Allard and Lindert are taking account of much longer-term behavior (i.e. over the span of decades) than in our results.

\subsection{Post-1995 Simulations}

Table 6 reports turnarounds in productivity and employment growth for the four country groups. Recall that all these results are based on regressions for the $14 \mathrm{EU}$ countries, and the country group averages emerge for expositional purposes only after the regressions are run. For each group, we report pre- and post-1995 growth rates for the actual data, predicted values from the regressions, and a counterfactual simulation in which the policy variables are fixed at their 1995 levels. 
It is easiest to understand the meaning of this simulation by taking an example. Let us begin with the data for labor productivity in the Mediterranean countries. For 1980-1995, the regression predicts annual LP growth of 2.12 percent. Had policy been fixed at its 1995 level for the entire period though, productivity growth would have been a somewhat slower 1.82 percent. So during that span, policy effects raised productivity growth by 0.30 percent per year. In the post-1995 sample, however, with fixed policy, productivity would have been 0.28 percent higher. The change following 1995 in the "policy effect" column is then the effect on productivity of the change in policy. For the Mediterranean countries, this comes out to be -0.58 percent. This is nearly half the predicted decline in productivity growth.

In all the country groups except the Anglo-Saxons, we estimate that policy and institutional changes after 1995 lowered productivity growth. As we just saw, for the Mediterranean countries, we estimate that policy choices lowered productivity growth by -0.58 percent per year. For the Continental countries, the effect was -0.15 percent, while in the Nordic countries, the effect was -0.47 percent. For the Anglo-Saxon countries, we estimate that policy changes actually raised productivity growth by 0.13 percent. This is because pre-1995, they were the only country group with policies that substantially lowered productivity growth.

Looking at the results of the simulations for employment, we find by far the largest effect in the Nordic and Mediterranean countries - policy choices raised growth in the employment rate by 0.46 percent per year in each group. In the Continental and Anglo-Saxon countries, policy actually lowered employment growth by 0.04 and 0.07 percent, respectively. This is consistent with the result that policy also had relatively small effects on productivity in these groups.

The bottom three rows of table 6 report the results for the full EU-15. For productivity, of the total negative turnaround of -0.89 percent, the policy variables drive -0.29 percent, about $1 / 3$. For employment, of the 1.31 percentage point increase in growth, only 0.26 percentage points, or $1 / 5$ of the total, is explained by the policy variables.

In general, the employment regressions do not explain much of the post-1995 change in employment - the post-1995 dummy is forced to explain the majority of the change. The average acceleration in employment growth across the four groups is 1.33 percent. Since the post-1995 dummy is estimated to be approximately 0.9 , there is not much left for the policy variables to explain. ${ }^{26}$

${ }^{26}$ The changes in the output gap can also explain some of the higher rate of employment growth following 1995. 
Figure 7 plots predictions for the EU-15 that are analogous to table 6. The top panel shows the predicted level of labor productivity, with a linear trend taken out to make it easier to understand. The linear trend is the average growth rate prior to 1995, so that the decline in the lines following 1995 shows how much productivity fell below where it would have been if had grown at its pre-1995 rate. The levels of productivity are all set to 100 in 1994 . The post-1995 turnaround is immediately apparent in the decline in the productivity lines displayed following 1995. For the counterfactual simulation, policy had roughly no effect prior to 1995, but subsequently, it lowered the level of productivity - accounting for a 2.5 percent decline in the level by 2003 - about $1 / 3$ of the total.

The third line in figure 7 shows what happens if the effects of the post-1995 dummy on employment are turned off. That is, we still allow the dummy to affect productivity directly, but we simulate employment following its pre-1995 growth rate. In order for this exercise to carry any meaning, we must assume that productivity changes did not drive the post-1995 acceleration in employment; i.e., this would be valid if the employment acceleration were driven by social factors. We then find that there would have been no decline at all in the level of productivity. In fact, productivity would have risen above its pre-1995 trend.

This is a key finding. If the employment shift in Europe was exogenous, it explains 100 percent of the decline in European productivity growth since 1995. This result is the same as the finding that the post-1995 dummy in the productivity regressions is not statistically significant - after controlling for employment and policy, there is no significant change in European productivity growth following 1995. ${ }^{27}$ However, we can explain only $1 / 3$ of the total decline in productivity using the policy and institutional variables.

The question then becomes whether the unexplained shift in employment was driven by changes in productivity or whether it was exogenous. The fact that the post1995 dummy is insignificant in the productivity regressions, along with the fact that the regressions using the post-1995 dummy pass the Sargan test for instrument validity, is evidence in favor of the proposition that employment was not driven by productivity. Furthermore, in section 5.4 above, we discuss social factors, separate from productivity, that could have driven the unexplained rise in employment. In the end, we have no statistical evidence that the rise in employment growth was driven by productivity, and we believe that there are social factors orthogonal to productivity that explain recent employment behavior. So there is a solid case to be made that in fact, we can explain $100 \%$ of the decline in European productivity, as a combination of labor market liberalization and social changes.

${ }^{27}$ When employment is dropped from the regression, the post-1995 dummy is significant with a coefficient of -0.70 . A similar regression for the US gives a mirror image positive coefficient of 0.70 . 
The bottom panel of Figure 7 shows employment results. In this case no trend is taken out. The effects of policy on employment are estimated to be smaller than for productivity. The employment rate is predicted to have risen by 10 percent following 1994 , but only 2.3 percent, or $1 / 5$, is driven by the policy variables. The counterfactual simulation does not begin to diverge noticeably until 1998. By construction, employment growth is flat when we drop the post-1995 dummy. So $4 / 5$ of the rise in employment following 1995 is driven by this unexplained residual.

\subsection{The Combined Effects of Policy and Institutions on Productivity Growth in Europe}

In order to get a better view of the effects of the policy variables on employment and productivity, we need to combine the effects that act through both stages of our 2SLS estimation. In particular, the policy variables all have effects on employment, which will affect productivity, and some also have independent effects on productivity growth. Table 7 reports results from this exercise. For each variable, we calculate the effect of a unit standard deviation shock, where the standard deviations are measures on post-2000 data (except for the high corporatism dummy, for which we simply look at what happens when it is turned on).

Column 1 reports the size of the shocks. Column 2 displays the effect on employment and column 3 the effect on productivity. In column 4, we calculate an implicit impact on output per capita where we assume that the variables have no effect on hours worked per employee. Standard errors calculated using the Delta method are reported in parentheses. Of the six variables studied, three have positive net effects on output per capita and three have negative effects. However, the standard errors on these estimates are fairly large - only three of the coefficients for output per capita are more than two standard errors away from zero.

The three variables with a positive net effect on output per capita are PMR, ARR and EPL. This result is caused by the fact that they all have independent positive effects on productivity that help overcome the negative effect on output from lower employment. Even in the case of no independent effects, the estimated elasticity of output with respect to employment is only -0.31 , so it does not take a big effect to overcome this. The effect of PMR on productivity has a very large standard error, so we do not put much weight on it. For EPL and ARR, on the other hand, the effects on productivity are highly significant. The positive effect on output per capita of EPL has a coefficient more than two standard errors away from zero, and the positive effect of the ARR on output per capita is close to twice its standard error.

For the tax wedge, we estimate that an increase of 9 percentage points (where the average level is 30.8 percent) lowers the employment rate by 2.67 percent, but only 
lowers output by 0.83 percent. This is a relatively small cost to a policy that chooses higher rather than lower taxes. Moreover, the standard error on this estimate is small only 0.4 percent.

The last of the three variables that has a statistically significant effect on output per capita is union density. The standard deviation of union density across Europe is 23.32 percentage points. An increase of this magnitude in union density is predicted to lower the employment rate by 7.93 percent. It raises productivity, however, by 5.07 percent. Its net effect on output per capita is then only -2.85 percent. This is still a large change, and the standard error is only 1.07 percentage points. Looking back at the timeseries plot of the policy variables in Figure 5, we see that changes in union density near the magnitude of 20 percentage points have indeed occurred within the time period of our data. In the Anglo-Saxon countries, union density declined by 20 percentage points between 1978 and 1998. In the Mediterranean and Continental countries, there were smaller declines of about 6 percentage points between 1993 and 2003.

Throughout the paper we have explored the interplay between changes in the growth rates of employment and productivity. Certain qualitative features are robust. First, the effects of the six policy and institutional variables on productivity are uniformly positive. This is due to the fact that they can work both directly and through decreasing employment. Second, union density has a robustly negative effect on output per capita, and EPL's effect is robustly positive. More importantly, we find this method a useful framework in which to understand the effects of policy on some of the major variables of concern in the macroeconomy.

The finding that the six policy and institutional variables all drive productivity up is, once again, surprising. It is worth taking a step back to consider exactly what this result means. First, note that we do not find that the variables all have direct effects on productivity-only EPL and ARR have significant coefficients in the second stage regressions. Moreover, one explanation for these two positive coefficients is that we are seeing residual effects of these variables on employment that are not captured by the first stage regression.

The second surprising result is that we find no bounce-back response of productivity to employment. That is, the lags of employment growth do not have positive coefficients, indicating that the short-run negative correlation between employment and productivity is actually a permanent effect. While this result is surprising, we are not aware of other researchers who have robustly found a bounceback. Only McGuckin and van Ark (2005) find that the relationship between 5-year growth rates of productivity and employment is not significantly different from zero, but they do not include as extensive a set of controls as we do. 
Macroeconomic theory tells us that we should expect a bounce-back. But theory does not always accord with the facts. Going beyond the data in Table 2 on the average post-1995 growth rates of capital per capita $(\mathrm{K} / \mathrm{N})$, we find a uniform pattern across all four European country groups that growth in $\mathrm{K} / \mathrm{N}$ declined, in some cases precipitously, in 2000-05 as compared to 1995-2000. This disappointing performance of capital growth lies behind our surprising result that the employment-productivity tradeoff was permanent, at least as far as our data extend, rather than temporary.

\section{CONCLUSIONS AND POLICY IMPLICATIONS}

The single most notable change after 1995 in Europe has been heterogeneity. Prior to 1995, European countries followed relatively similar paths. They had high growth rates of productivity, and were converging to the productivity level of the US. At the same time, they were experiencing high levels of unemployment and little employment growth. .

Following 1995, European countries also diverged from each other. In some, we observe impressive employment growth, both due to policy and to cultural factors including immigration and a greater acceptance of women entering the workforce; in other countries, employment grew more slowly. This paper studies the negative correlation between growth in labor productivity and employment per capita, country by country and year by year. We link changes in policy and institutional variables to both changes in growth rates of labor productivity and of employment per capita. We use statistical methods to control for reverse feedback from productivity to employment, and we find dual effects of policy on labor productivity and employment. Our baseline results in Table 6 suggest that, at least in the short run, lower taxes and looser regulations raise employment growth and reduce productivity growth. We have identified this negative correlation in reduced-form regressions that allow both direct and indirect effects of changes in the policy and institutional variables on productivity growth.

The post-1995 heterogeneity across Europe provides a fertile setting in which to study the effects of various policy changes, and this heterogeneity helps us to find significant effects of policy and institutional variables not only on employment per capita and on productivity, but also on output per capita. We find that by reducing EPL, PMR, unemployment benefits, and average tax rates, countries cause productivity growth to decline, partly or completely offsetting the benefit of higher employment.

Ultimately, the effects of these policy changes on output per capita are ambiguous. Some factors, such as unions, seem to have a strong negative effect on output per capita. On the other hand, EPL and unemployment benefits have a positive effect on output per capita. PMR and the tax wedge, as far as we can tell, have roughly no effects. It is 
certainly true that these results can be fragile, and there are wide confidence intervals around some but not all of our estimates.

Surprisingly, we find that every one percentage point increase in the tax wedge only lowers output per capita by 0.1 percent. Since the coefficient on taxes in the employment regressions is estimated to be approximately -0.3 , the tradeoff between less work and only slightly less income should not be rejected out of hand in the perspective of the valuable social services that these taxes can finance.

More generally, the most important innovation of our approach to these policy questions is to change the current focus of European policy discussions. Europeans in the Lisbon Agenda placed major emphasis on raising employment per capita, especially of females, but now lament that their productivity and TFP growth has been slower than the US since 1995. Our analysis suggests that some of the policy reforms that are at the top of the European reform agenda may raise employment per capita but may also reduce productivity, leaving as in our simulations perhaps negligible effects on output per capita. ${ }^{28}$

The reason we find that these policies work is that when employment growth rises, labor productivity growth declines. If workers were homogeneous, we would expect the elasticity of productivity to employment to equal, at most, to capital's share of income, about $1 / 3$. We find an elasticity of at least -0.5 . This implies a further effect from the fact that marginal workers tend to be the least skilled and experienced. This is in accord with our finding that most of the additional workers have been females with little previous work experience, and that the recent rise of employment also in some countries such as Spain consists to a substantial degree of immigrants.

One interpretation of our results is that had employment not risen in Europe following 1995, labor productivity growth would not have slowed. In the US though, after controlling for employment and policy, there was still an unexplained rise in productivity growth. This is reflected in the acceleration of US TFP relative to the EU. In other words, even if employment had not risen in Europe, productivity growth would still have slowed relative to the US. Since we do not model TFP in this paper, we cannot explain the divergence in TFP trends.

Laws that protect incumbents and limit entrance to markets tend to inhibit adoption of new technologies. While two of our policy variables (EPL and ARR) seem to go in the direction of raising income per capita, the effects of regulation on technological change must also be taken into account and this additional channel is outside of the

\footnotetext{
${ }^{28}$ The policy tradeoff emphasized here is not unique to our paper. Pichelmann and Roeger (2008) have the same point of departure as this paper about the policy tradeoff. They minimize its empirical importance based on a simple three-equal VAR model that does not address any of the issues of simultaneity and endogeneity upon which we focus here.
} 
scope of our analysis. In the end, a policy should be judged based on two effects: a static effect and a dynamic effect. When a policy reform is first enacted, it will have an immediate impact in raising employment while reducing productivity. This is the shortrun static effect that is the subject of this paper. In the long run, there are two important dynamic effects. The first is that investment may rise after employment rises. The second is that when policy reforms raise the incentives for adoption of new technologies, an economy may adopt new technologies faster and move closer to the technological frontier.

This paper has been only about the static effect. Moreover, we looked for the first of the two dynamic effects - the response of investment to employment changes and were unable to find it. In particular, the growth of capital per capita slowed rather than increased between 2000 and 2005. However, the second dynamic effect is critical to the long run prosperity of Europe. Creation and adoption of new technology is the engine that drives long run growth. The effects of unemployment benefits are probably driven by their static component. On the other hand, we find that product market regulation has few static effects, and it is likely mainly a dynamic policy. In the long run, liberalization that encourages competition will be a good thing. This paper shows that liberalization can have short run costs, but when the long run benefits are large, those costs should not dissuade policymakers from making the right decision. 


\section{REFERENCES}

Acemoglu, D. and R. Shimer (1999). “Efficient Unemployment Insurance," Journal of Political Economy, 107, 893-928.

Acemoglu, D. and R. Shimer (2000). “Productivity Gains from Unemployment Insurance." European Economic Review, 44, 1195-1224.

Alesina, A., and F. Giavazzi (2006). The Future of Europe: Reform or Decline? MIT Press.

Alesina, A., E. Glaeser, and B. Sacerdote (2006). "Work and Leisure in the United States and Europe: Why So Different?" NBER Macroeconomics Annual 2005, April, 1-64.

Allard, G.J. and P.H. Lindert (2006). “Euro-Productivity and Euro-Job since the 1960s: Which Institutions Really Mattered?" NBER Working Paper 12460, August.

Baily, M. N. and J. Kirkegaard (2004). Transforming the European Economy, Institute for International Economics, Washington, D. C.

Bassanini, A. and R. Duval (2006). “Employment Patterns in OECD Countries: Reassessing the Role of Policies and Institutions". OECD Social, Employment, and Migration Working Paper no. 35.

Bassanini, A., S. Scarpetta, and P. Hemmings (2001). "Economic Growth: the Role of Policies and Institutions. Panel Evidence from OECD Countries." OECD Economics Department Working Paper no. 283.

Beaudry, P. and F. Collard (2001). “Why has the Employment-Productivity Tradeoff among Industrialized Countries been so Strong?" UBC working paper, September.

Beaudry, P., F. Collard, and D.A. Green (2005). "Demographics and Recent Productivity Performances: Insights from Cross Country Comparisons." Mimeo.

Bentolila, S., J. J. Dolado, and J. F. Jimeno (2007). “Does Immigration Affect the Phillips Curve? Some Evidence for Spain," mimeo, May.

Bertola, G., F. D. Blau and L. Kahn (2002). "Labor Market Institutions and Demographic Employment Pattern," Discussion Paper no. 3448, Centre for Economic Policy Research, London.

Blanchard, O.J. (1997). “The Medium Run,” Brookings Papers on Economic Activity, 2, 89158. 
Blanchard, O.J. and J. Wolfers (2000). “The Role of Shocks and Institutions in the Rise of European Unemployment: The Aggregate Evidence," The Economic Journal, 110, March, C1-C33.

Boeri, T., D. Del Boca, and C. Pissarides (2005). Women at Work: An Economic Perspective. Oxford University Press, Oxford and New York.

Bourles, R. and G. Cette (2005). "A Comparison of Structural Productivity Levels in the Major Industrialised Countries." OECD Economic Studies no. 41.

Davis, S.J. and M. Henrekson (2004). “Tax Effects on Work Activity, Industry Mix, and Shadow Economy Size: Evidence from Rich-Country Comparisons," NBER Working Paper 10509, May.

Eichengreen, B., M. Landesmann, and D. Stiefel (2008). The European Economy in an American Mirror. Abingdon UK and New York, Routledge.

Freeman, Richard B. (2008). "How Well do the Clothes Fit? Priors and Evidence in the Debate over Flexibility and Labor Market Performance" in B. Eichengreen et al. (2008), 104-16.

Galor, O. and D. N. Weil (1996). “The Gender Gap, Fertility and Growth,” American Economic Review, 86, June, 374-87.

Gordon, R.J. (1997). "Is There a Tradeoff between Unemployment and Productivity Growth?" in D. Snower and G. de la Dehasa, eds., Unemployment Policy: Government Options for the Labor Market. Cambridge U.K.: Cambridge University Press, 433-463.

Heinz, F.F. and M. Ward-Warmedinger (2005). “Cross-border Labor Mobility within an enlarged EU," ECB Occasional Paper, July.

Izquierdo, M. and J.F. Jimeno (2007). “On the Aggregate Effects of Immigration in Spain." Banco de Espana Working Paper no. 0714.

Lagos, R. (2006). “A Model of TFP." Review of Economic Studies, 73, October, 983-1007.

Layard, R., S. Nickell, and R. Jackman (2005). Unemployment: Macroeconomic Performance and the Labor Market, Oxford University Press.

Ljungqvist, L. and T.J. Sargent (2006). "Indivisible Labor, Human Capital, Lotteries, and Personal Savings: Do Taxes Explain European Employment?" presented at 
NBER Macroannual conference, April 7-8.

Mankiw, N.G., D. Romer, and D.N. Weil (1992). "A Contribution to the Empirics of Economic Growth." The Quarterly Journal of Economics, 107, May, 407-437.

McGuckin, R. and B. van Ark (2005). "Productivity and Participation: An International Comparison," Groningen Growth and Development Centre, Research Memorandum GD-78, August.

Nickell, S. (1981). "Biases in Dynamic Models with Fixed Effects," Econometrica, 49, November: 1417-1426.

Nickell, S., L. Nunziata, and W. Ochel (2005). “Unemployment in the OECD since the 1960s: What do we know? Economic Journal, 115, January, 1-27.

Nikoletti, G. and S. Scarpetta (2003). "Regulation, Productivity, and Growth, OECD Evidence," OECD Policy Research Working Paper no. 2944.

OECD (2006). OECD Employment Outlook: Boosting Jobs and Incomes. Paris.

Ohanian, L., A. Raffo, and R. Rogerson (2007). “Work and Taxes: Allocation of Time in OECD Countries," Federal Reserve Bank of Kansas City Economic Review, 92, 3, 3758.

Olivetti, C. (2006). “Changes in Women's Hours of Market Work: The Role of Returns to Experience," Review of Economic Dynamics, 9, October, 557-587.

Paramio, J.L. and J. L. Zofio (2005). “Labor Market Duality and Leisure Industries in Spain: Quality of Life versus Standard of Living," Mimeo.

Pichelmann, K, and W. Roeger (2008). “Employment and Labor Productivity in the EU: Reconsidering a Potential Trade-off in the Lisbon Strategy," in Eichengreen, et al., $128-42$.

Pissarides, C., et al. (2005). "Women in the Labor Force: How Well is Europe Doing?" in Boeri, Del Boca, and Pissarides (2005), 7-120.

Prescott, E.C. (2004). "Why Do Americans Work So Much More than Europeans?" Federal Reserve Bank of Minneapolis Quarterly Review, 28, July, 2-13.

Ramsey, F.P. (1928). "A Mathematical Theory of Saving", The Economic Journal, 38, December, 543-559. 
Rogerson, R. (2005). “Comments" on Pissarides et. Al. (2005), in Boeri, Del Boca, and Pissarides (2005), 109-114.

Romer, P.M. (1987). "Crazy Explanations for the Productivity Slowdown." NBER Macroeconomics Annual 1987, December, 163-201.

Schwerdt, G. and J. Turunen (2006). “Growth in Euro Area Labor Quality.” European Central Bank Working Paper no. 575.

Stiroh, K.J. (2002). “Information Technology and the US Productivity Revival: What do the Industry Data Say?" The American Economic Review, 92, December, 1559-1576. 


\section{APPENDIX A. ROBUSTNESS TESTS}

Tables A1 and A2 provide robustness tests for the employment and productivity regressions, respectively. The first two columns of table A1 remove Spain and then the Mediterranean countries from the sample. The post-1995 dummy falls from its estimate of approximately 0.9 in the main text, to roughly 0.7 However, the change is not statistically significant. In column 3 we add the US to the sample and find similar results as in the main text. The US has a negative post-1995 dummy of -0.38 , and the coefficient on PMR becomes significant. Since we use population weights, the results in column 3 are largely driven by the US. Last, column 5 lags all of the explanatory variables by 1 year in order to avoid any possible simultaneity. The results do not change notably.

Table A2 presents robustness tests for the productivity regressions. Column 1 removes the Mediterranean countries from the sample. The coefficient on employment is now only significant at the 5 percent level, rather than the 1 percent level, because the standard error is larger. EPL also loses its significant coefficient. In column 2, we try dropping the output gap, since it could cause simultaneity bias in our results. The coefficient on employment rises to -0.46 . This is likely due to the fact that the regression is now picking up some of the short-run correlation between employment and productivity.

In columns 3 and 4 , we lag all of the explanatory variables by one year except for the output gap. Using only the tax wedge as an instrument, the coefficient on employment is no longer significant, as its standard error is relatively large. The 95 percent confidence interval extends from -0.75 to 0.25 . Column 4 adds union density and high corporatism as dummies. This brings the standard error down and makes the coefficient significant at the 1 percent level. Column 5 shows that excluding the tax wedge from the regression does not affect the results.

Columns 6 and 7 add the US to the analysis. As before, since we use population weights, the US data dominates the sample. In column 6, the point estimate on employment is in line with other columns, but the standard error has risen to 0.31. In column 7 , using a full set of instruments, employment is once again significant at the 1 percent level.

Looking across the columns, the positive coefficients on EPL and ARR are clearly very robust to a variety of specifications. The point estimate on the post-1995 dummy is usually negative, but it is never statistically significant at even the 10 percent level. In the US, on the other hand, the post-1995 dummy has a coefficient of 0.45 , which is significant at the 1 percent level. So while it seems that there was no exogenous negative shock to European productivity growth, there was some sort of positive shock for the US. 


\section{APPENDIX B. DATA SOURCES BY ORDER OF APPEARANCE}

\section{Section 2.2}

Source: GGDC Total Economy Database, Jan. 2007. http://www.ggdc.net/indexdseries.html:

Output (1970-2006): Linear average of GK and EKS measures of GDP. Data adjustments: Values for Germany ratio linked to W. Germany (GK only) in 1989. USA measures are from BEA NIPA Table 1.1.6 (last updated July 27, 2007). USA measures for Table 2 are from GGDC as defined above for the sake of uniformity when comparing levels.

Hours (1970-2006): Total annual hours worked.

Data adjustments: Values for Germany ratio linked to W. Germany in 1989. USA measures are the latest BLS numbers released August 7, 2007 provided by Phyllis Otto via email.

Population (1970-2006): Midyear population.

Data adjustments: Values for Germany ratio linked to W. Germany in 1989

Employment (1970-2006): Persons engaged.

Data adjustments: Values for Germany ratio linked to W. Germany in 1989

Source: EU KLEMS Database, Mar. 2007. http://www.euklems.net:

Gross Output (1979-2004): Price indexes, 1995=100. Basic Files, tab "GO_P." Data adjustments: Due to missing data, Greece GO_P values were set equal to tab "VA_P" (Value Added Price Index) values from 1979-1994. Also due to missing data, GO_P values for Luxembourg industries 21 t22 and 34t35 were set equal to industry D from 1979-1994.

1997 Purchasing Power Parity (PPP) Index: National currency per 1997 German Euro.

Nominal Capital Compensation (1979-2004): Basic Files, tab "CAP."

Data adjustments: Negative CAP observations were replaced by multiplying VA by Total Economy CAP divided by Total Economy VA in that year.

Notes: Nominal amounts converted to German Euros by 1997 industry PPP's using the formula:

'CAP in 1997 German Euros = CAP in national currency / [((GO_P / 1997 GO_P) /

(German GO_P / 1997 German GO_P)) * 1997 PPP].'

Real Growth in Capital (1980-2004): Basic Files, tab “CAP_QI." 
Data adjustments: No CAP_QI data is available for Greece, Netherlands, and Portugal. These countries are therefore dropped from all calculations involving capital. No significant difference arises in non-capital measures from the exclusion of these three countries, and thus we continue to use the entire EU-15 when possible. No CAP_QI data is available before 1993 for Sweden. Therefore, Sweden was dropped from all calculations involving capital prior to 1993.

Notes: Real growth of aggregated and sub-aggregated industries and countries calculated using a weighted average of the components' real growth rates. The weighted average is calculated using the geometric mean across each year pair of the industry or country's nominal share of capital compensation.

Hours (1980-2004): Total hours worked by persons engaged. Basic Files, tab "H_EMP."

Nominal Value Added (1979-2004): Gross value added. Basic Files, tab "VA." Notes: Nominal amounts converted to German Euros by 1997 industry PPP's using the formula:

'VA in 1997 German Euros = VA in national currency / [((GO_P / 1997 GO_P) / (German GO_P / 1997 German GO_P)) * 1997 PPP].'

Real Growth in Value Added (1980-2004): Basic Files, tab "VA_QI."

Notes: Real growth of aggregated and sub-aggregated industries and countries calculated using a weighted average of the components' real growth rates. The weighted average is calculated using the geometric mean across each year pair of the industry or country's nominal share of gross value added.

Capital's Share in Total Output (1980-2004): Geometric mean across each year pair of nominal capital divided by nominal value added.

Capital Deepening Growth (1980-2004): (Real capital growth minus growth in total hours worked multiplied by capital's share in total output.

Total Factor Productivity (TFP) Growth (1980-2004): Output per hour growth minus capital deepening growth.

Employment (1980-2004): Number of persons engaged. Basic Files, tab “EMP."

\section{EU-KLEMS Notes:}

Due to missing data: All values for Ireland industry $71 \mathrm{t} 74$ set equal to Ireland industry K before 1995, all nominal values for Ireland industries $60 t 63$ and 64 set equal to $0.5^{*}$ Ireland industry I before 1995, all index values for Ireland industries 60t63 and 64 set equal to Ireland industry I before 1995, and all index values for Germany industries 60 t63 and 64 set equal to Germany industry I before 1991. 
Aggregated total economy results may not match up perfectly to comparable estimates in the EU-KLEMS Database because we used their total economy PPP's to convert total economy numbers to a common currency, whereas EU-KLEMS only converted by industry and then added up the converted industry numbers to make a converted total economy total. We did it this way to keep total economy growth rates by country equal to the estimates given on the EU-KLEMS website. Converting by industry and then summing to make new total economy values distorts these growth rates.

\section{Section 3.2.2}

Source: OECD Population and Labor Force Statistics, Volume 2006 release 02. http://www.oecd.org:

Employment per Capita (1978-2003): Employment divided by population for men, women, and combined.

Source: Allard-Lindert Database, Jan. 2006. See website for their sources and data adjustments. http://www.econ.ucdavis.edu/faculty/fzlinder/OECD_19502001 annual1.xls:

Labor Tax Wedge (1978-2001): Total tax wedge including employer's social security contributions.

EPL (1978-2001): The Allard (2003) measure of the strictness of employee protection laws.

Source: GGDC Total Economy Database, Jan. 2007. http://www.ggdc.net/indexdseries.html:

Output Gap (1978-2003): Measure of the gap between actual and potential output as a percentage of potential output. Potential output created using a Hodrick-Prescott filter. For specific calculations, see our Stata do-file.

Source: Bassanini-Duval Dataset, obtained via email in April 2007. See Bassanini-Duval (2006) for their sources and data adjustments.

Labor Tax Wedge (1978-2003): Tax wedge between the labor cost to the employer and the corresponding net take-home pay of the employee for a single-earner couple with two children earning $100 \%$ of APW earnings. The tax wedge expresses the sum of personal income tax and all social security contributions as a percentage of total labor cost. 
Data adjustments: Data ratio linked to Allard-Lindert's tax wedge measure for missing years.

EPL (1978-2003): OECD summary indicator of the stringency of employment protection legislation.

Data adjustments: Data ratio linked to Allard-Lindert's EPL measure prior to 1982.

ARR (1978-2003): Average unemployment benefit replacement rate across two income situations (100\% and 67\% of APW earnings), three family situations (single, with dependent spouse, with spouse in work) and three different unemployment durations (1st year, 2nd and 3rd years, and 4th and 5th years of unemployment).

PMR (1978-2003): OECD summary indicator of regulatory impediments to product market competition in seven non-manufacturing industries: gas, electricity, post, telecoms (mobile and fixed services), passenger air transport, railways (passenger and freight services) and road freight.

Union Density (1978-2003): Trade union density rate.

Data adjustments: Due to missing data, data for Finland, Germany, and Sweden years 1991 and 1992 obtained by linear interpolation. Data for Greece years 2002 and 2003 set equal to Greece 2001. Data for Spain years 1978, 1979, and 1980 set equal to Spain 1981.

Output Gap (1978-2003): OECD measure of the gap between actual and potential output as a percentage of potential output.

Data adjustments: Data ratio linked to output gap measure derived from the GGDC Total Economy Database for missing years.

Notes: Output gap measures are updated from Bassanini and Duval's paper. They used output gap measures from OECD Economic Outlook 76, December 2004. The OECD output gap measure was chosen in favor of the output gap measure derived from the GGDC using an H-P trend because the OECD measure has more plausible gaps and more stable growth rates of potential output.

Degree of Corporatism (1978-2003): Indicator of the degree of centralization/coordination of the wage bargaining processes, which takes a value of 1 for high degrees of centralization and coordination and zero otherwise.

\section{Demographic Predictions}

Predictions for future demographic trends were downloaded from the UN's "World Population Prospects" database at http://esa.un.org/unpp/index.asp?panel=2.

\section{Additional Notes on the Productivity Regressions}


The regressions all pass the standard specification tests. In particular, the Sargan test indicates that our instruments are valid, the $\mathrm{Wu}$-Hausmann test rejects the null that employment growth is not endogenous, and the Cragg-Donald test for identification rejects the null that the model is underidentified at the .01 percent level.

The coefficients we find are nearly identical to those found by Bourles and Cette (2005), but are larger than those found by McGuckin and van Ark. Their sample is different from ours in its time period and selection of countries. Moreover, in at least some of their regressions, they do not control for the business cycle. Given the short run positive correlation between output, productivity and employment, we would expect the exclusion of the output gap to bias the estimated coefficient on employment upwards. In unreported experiments, we find that it does.

The other controls we include on the right hand side are slightly different from both Bourles and Cette (2005) and McGuckin and van Ark (2005). We try to be as careful as possible in avoiding simultaneity bias, which leads us to use fewer controls than Bourles and Cette.

\section{Stata Commands}

We used extensively the ivreg2 and xtivreg2 commands in stata:

Baum, C.F., Schaffer, M.E., Stillman, S., 2006. ivreg2: Stata module for extended instrumental variables/2SLS, GMM and AC/HAC, LIML and k-class regression. http://ideas.repec.org/c/boc/bocode/s425401.html

Schaffer, M.E., Stillman, S., 2007. xtivreg2: Stata module to perform extended IV/2SLS, GMM and AC/HAC, LIML and k-class regression for panel data models. http://ideas.repec.org/c/boc/bocode/s456501.html

\section{Other Notes:}

All trends were generated using Hodrick-Prescott filter with annual data smoothing parameter of 6.25. An extra year was added on to smooth the end of each trend. The value given to this year equaled the average growth rate of previous four years.

Growth rates were generated using the exponential growth rate formula. 


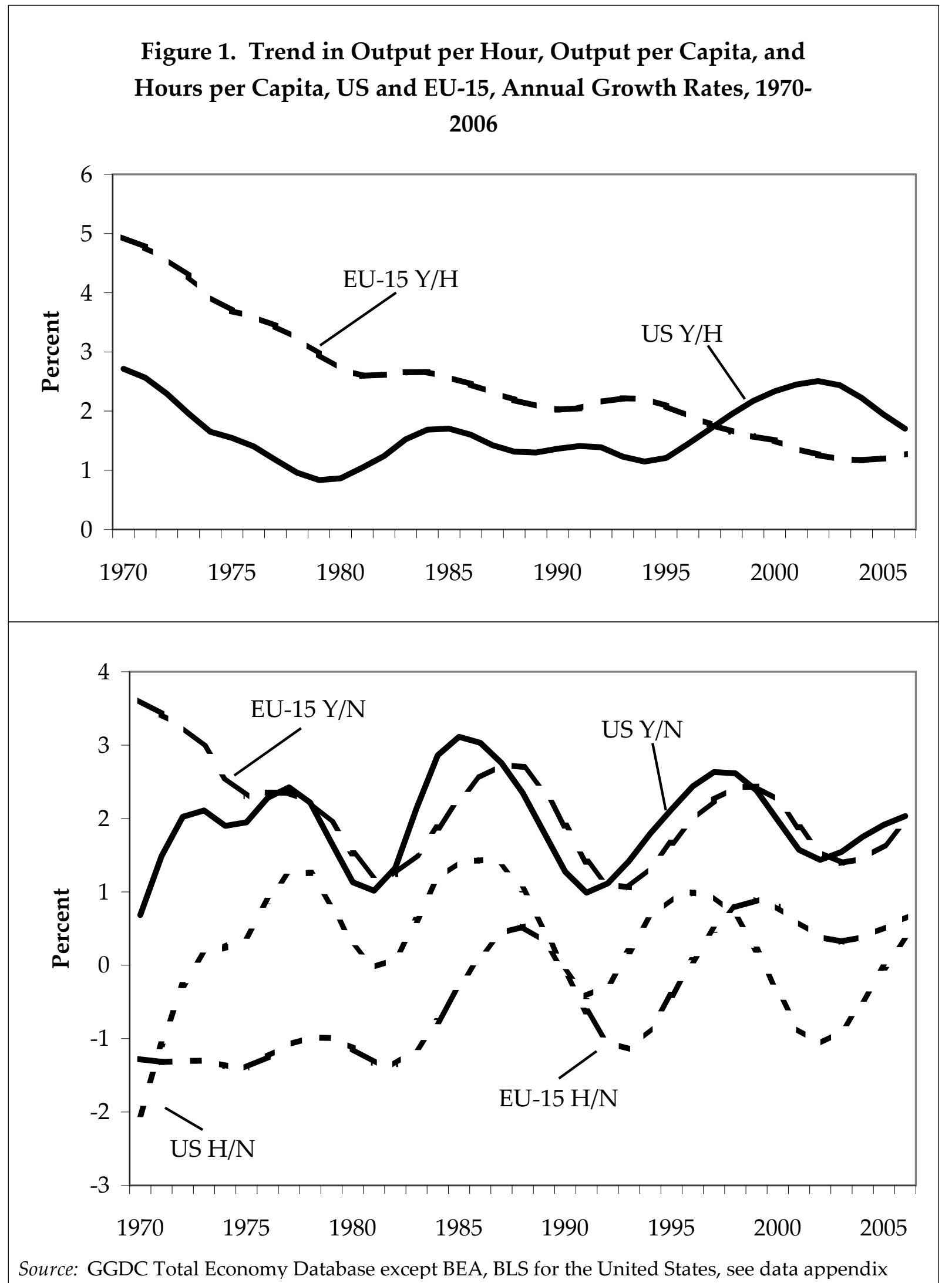




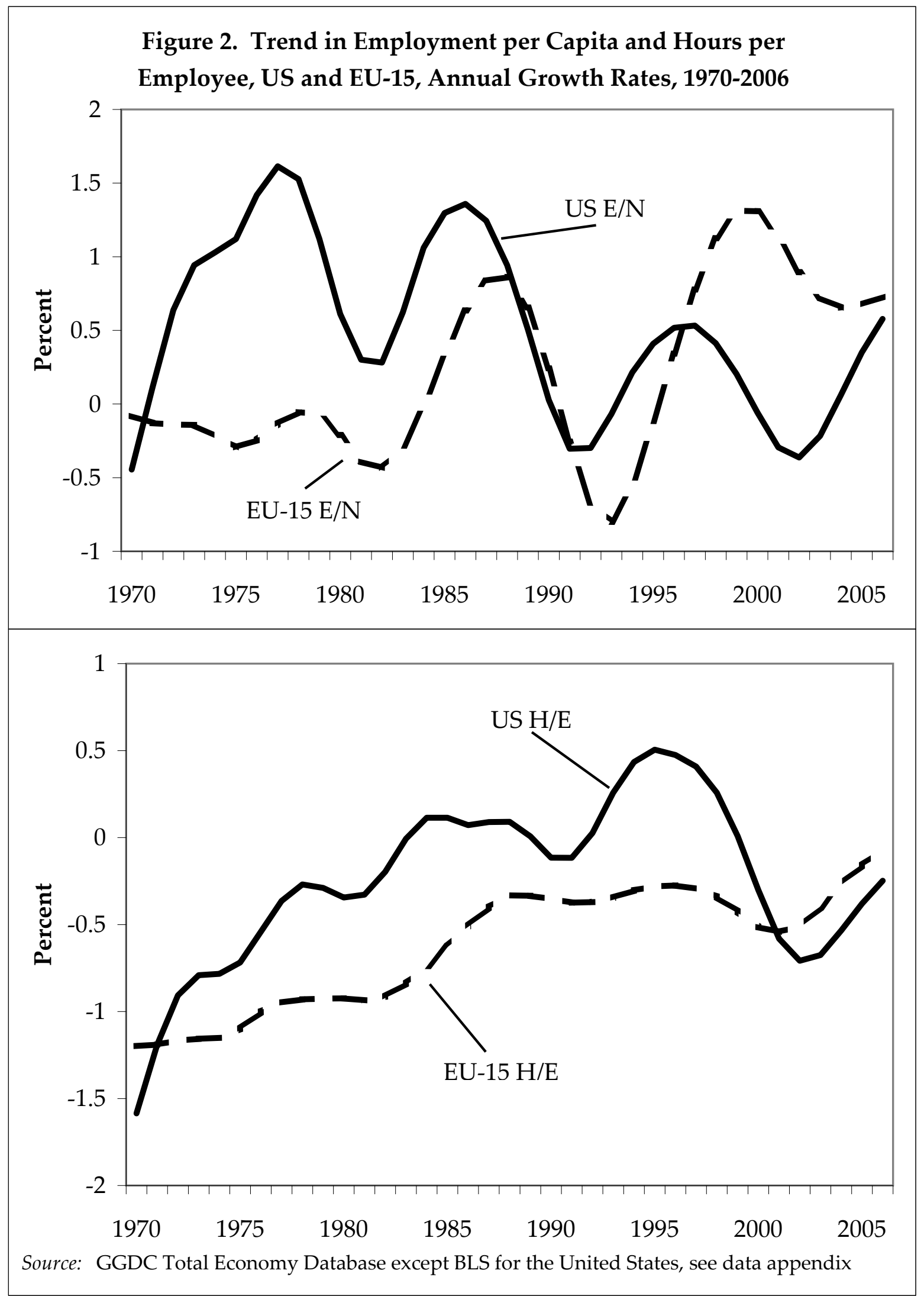




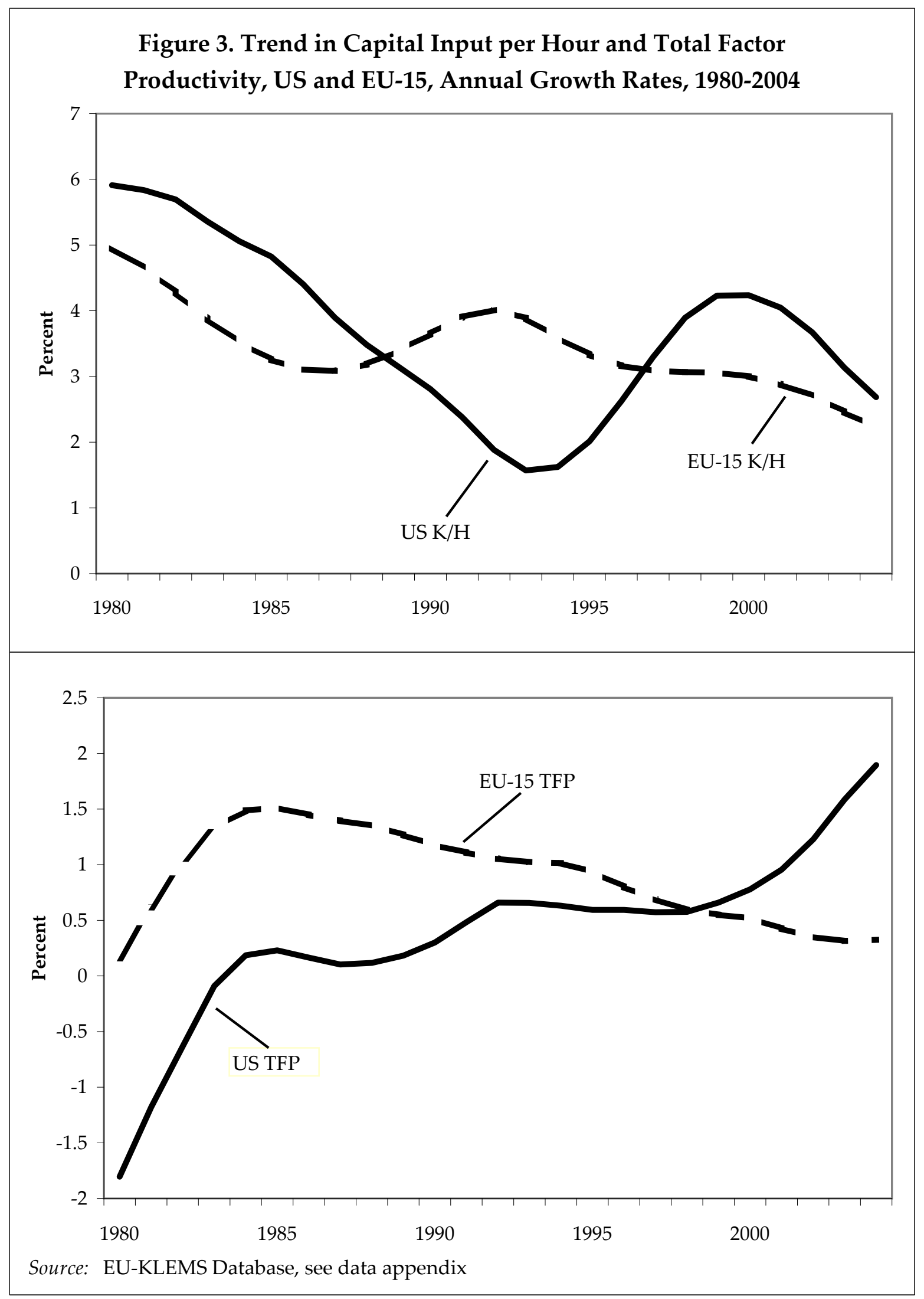


Figure 4: Employment and Share effects for the Turnaround in Employment per Capita Growth, 1995-2005 versus 1985-1995
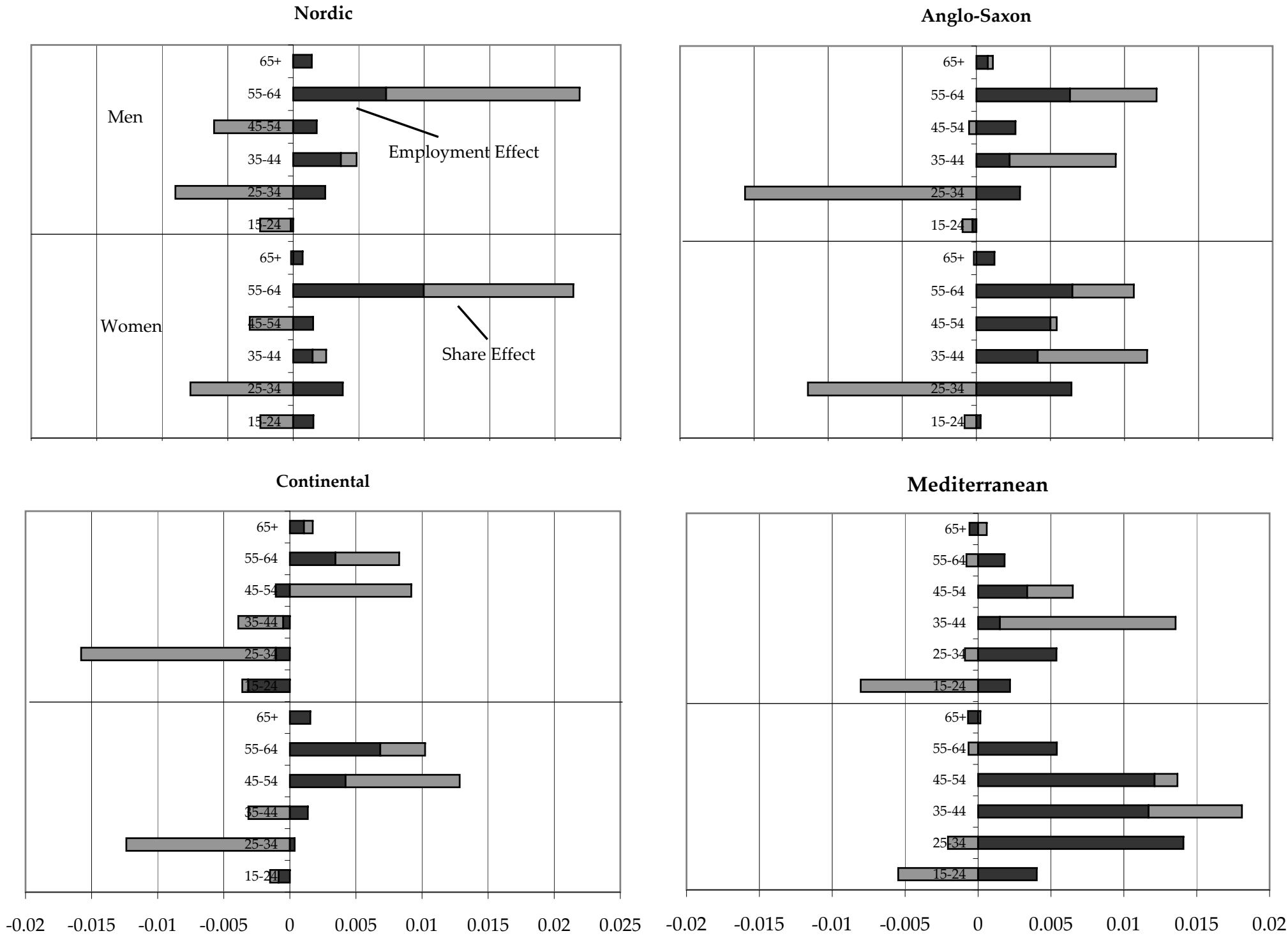

Source: Authors' calculations 
Figure 5. Policy and Institutional Variables, 1980-2003
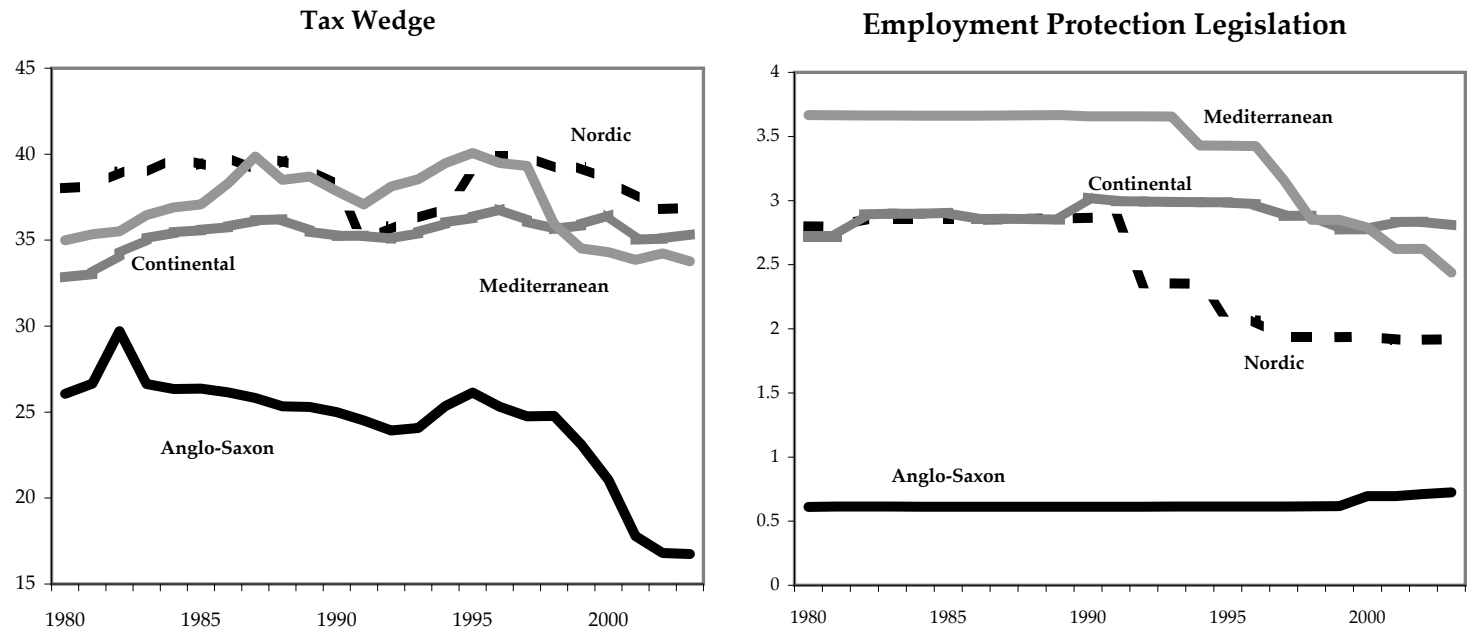

Product Market Regulations
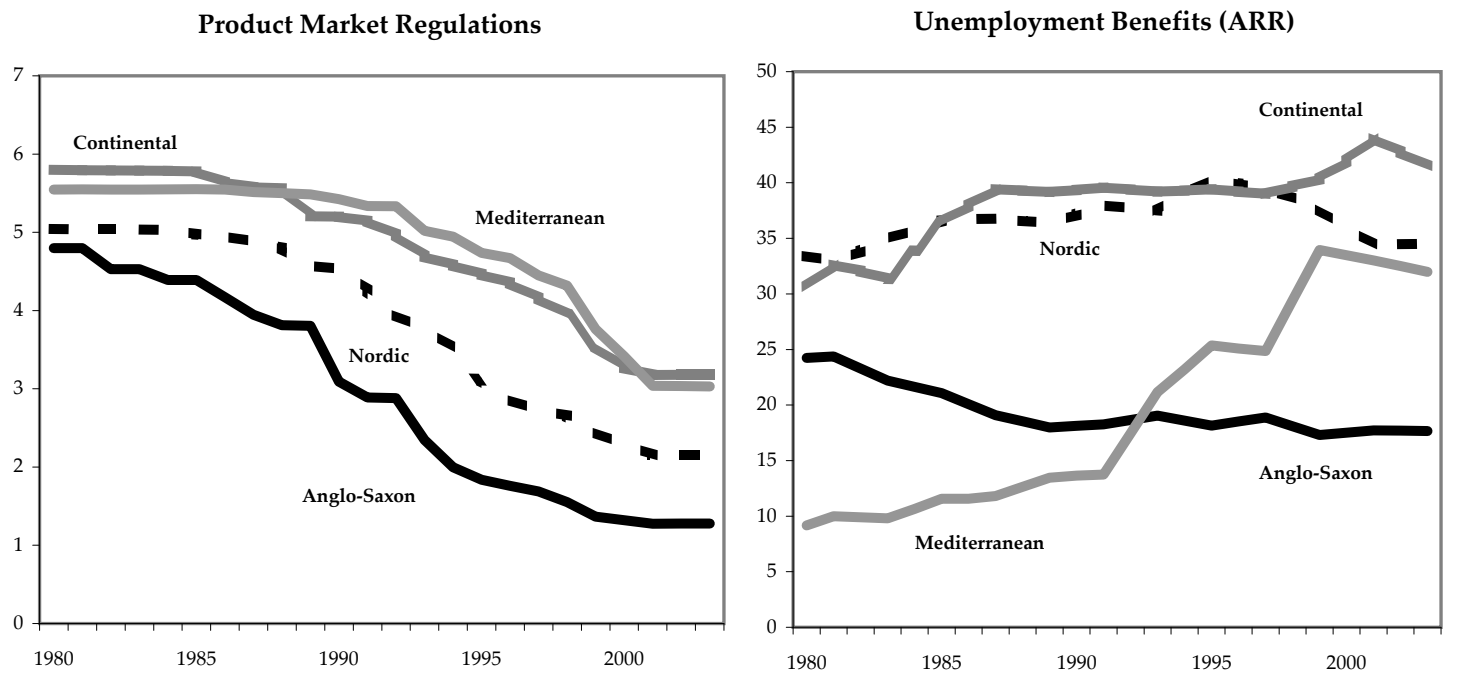

Union Density

High Corpratism Dummy
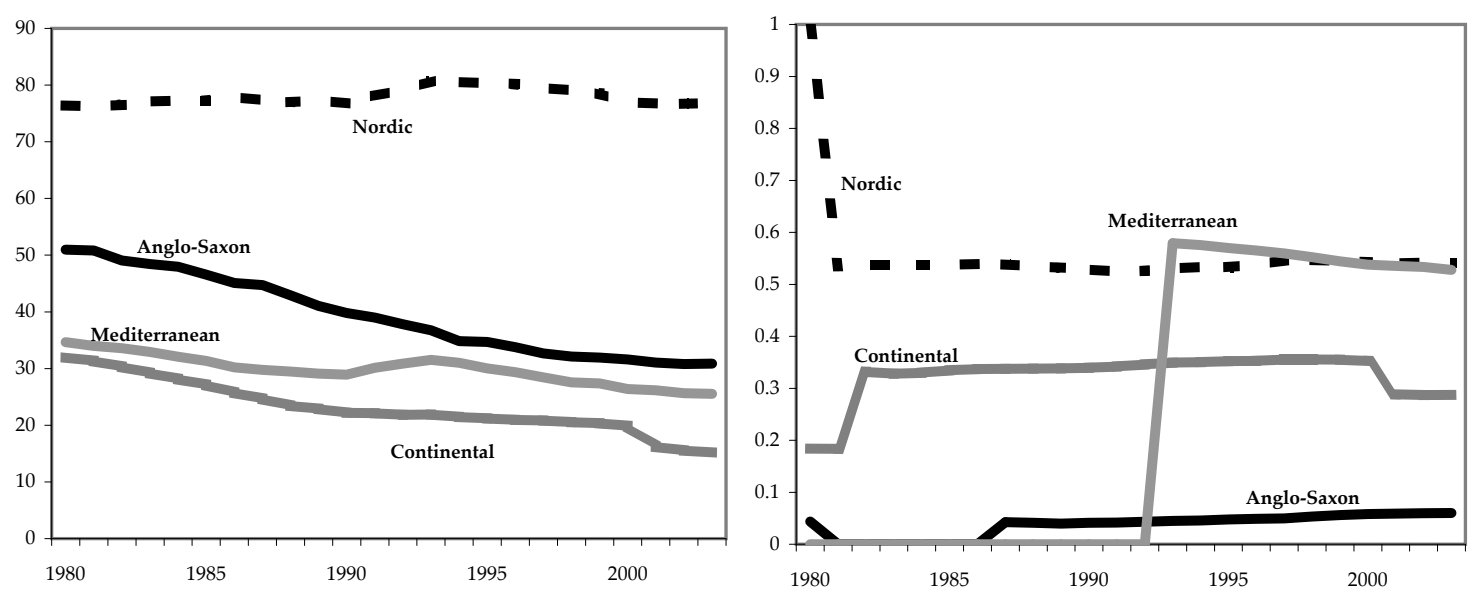

Source: Authors' calculations 
Figure 6: EU-15 Male and Female Employment per Capita Simulations, 1980-2003
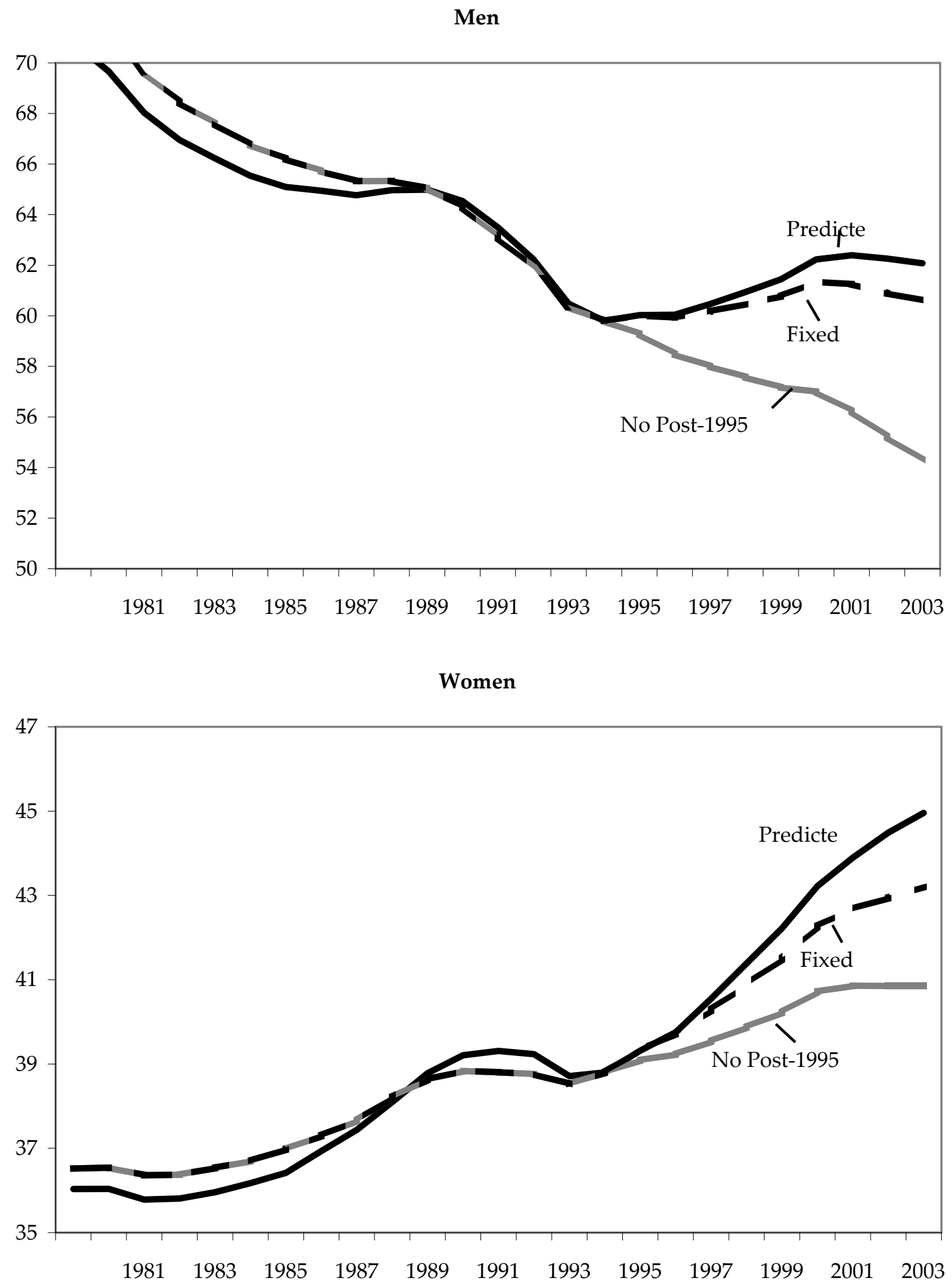

Source: Author's Calculations 
Figure 7: Actual, Predicted, and Fixed-Policy Labor Productivity and Employment
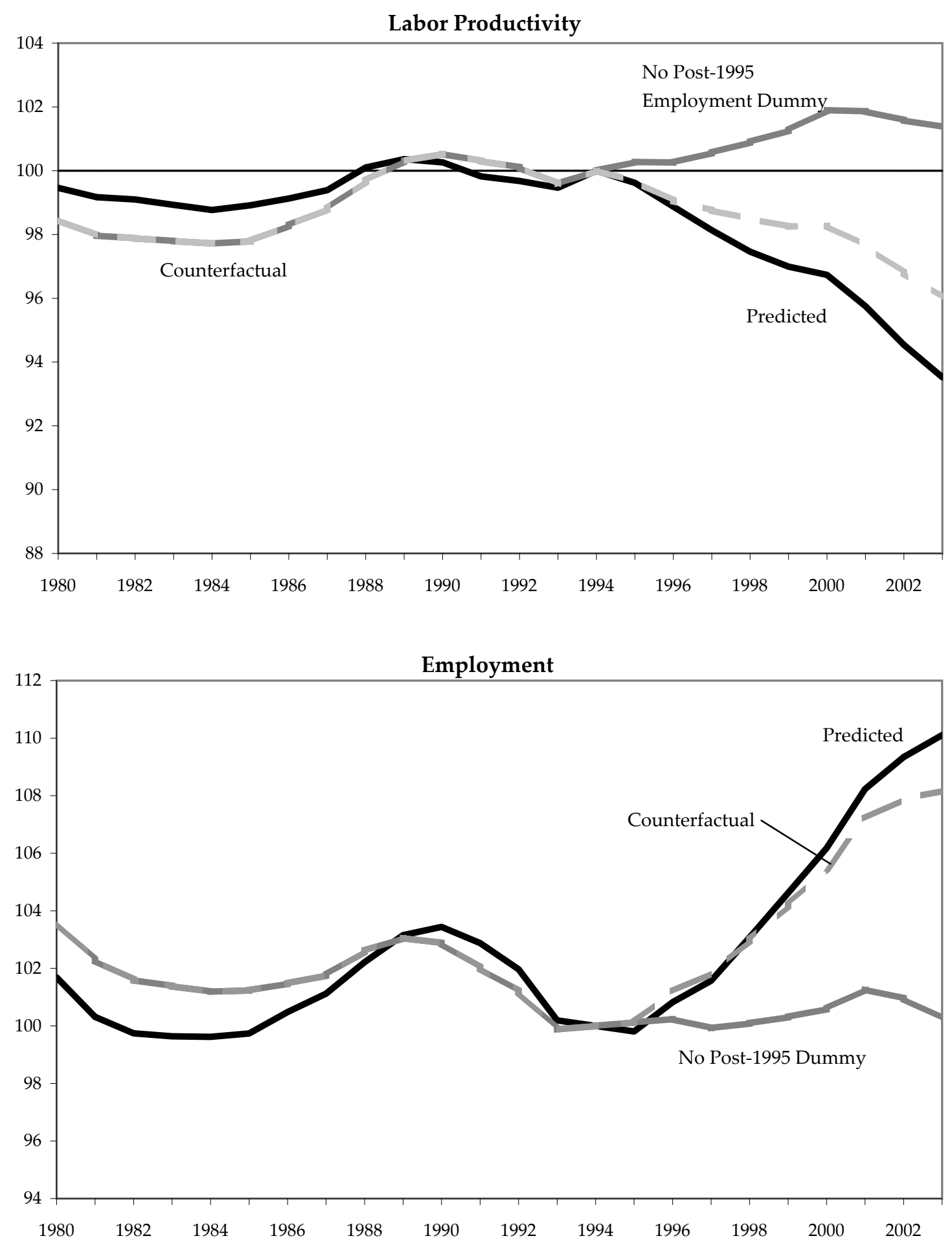

Source: Author's Calculations 


\begin{tabular}{|c|c|c|c|c|c|c|c|c|c|}
\hline \multicolumn{10}{|c|}{ Table 1} \\
\hline & \multicolumn{3}{|c|}{$\begin{array}{c}\text { Labour Productivity } \\
\text { Growth Rates }\end{array}$} & \multicolumn{3}{|c|}{$\begin{array}{c}\text { Hours per Capita } \\
\text { Growth Rates }\end{array}$} & \multicolumn{3}{|c|}{$\begin{array}{c}\text { Output per Capita } \\
\text { Growth Rates }\end{array}$} \\
\hline & 1970-1995 & 1995-2006 & Difference & 1970-1995 & $1995-2006$ & Difference & 1970-1995 & 1995-2006 & Difference \\
\hline United States & 1.42 & 2.13 & 0.71 & 0.55 & -0.04 & -0.58 & 1.97 & 2.09 & 0.12 \\
\hline EU-15 & 2.89 & 1.41 & -1.49 & -0.82 & 0.59 & 1.41 & 2.07 & 2.00 & -0.07 \\
\hline EU-15xMed & 2.81 & 1.87 & -0.94 & -0.84 & 0.07 & 0.92 & 1.97 & 1.94 & -0.03 \\
\hline Nordic & 2.41 & 2.09 & -0.32 & -0.77 & 0.56 & 1.33 & 1.64 & 2.66 & 1.02 \\
\hline Denmark & 2.74 & 1.15 & -1.59 & -0.85 & 0.67 & 1.52 & 1.89 & 1.82 & -0.07 \\
\hline Finland & 3.29 & 2.48 & -0.80 & -1.27 & 0.97 & 2.24 & 2.02 & 3.45 & 1.44 \\
\hline Sweden & 1.72 & 2.49 & 0.76 & -0.41 & 0.26 & 0.68 & 1.31 & 2.75 & 1.44 \\
\hline Anglo-Saxon & 2.73 & 2.18 & -0.55 & -0.72 & 0.46 & 1.18 & 2.01 & 2.64 & 0.63 \\
\hline Ireland & 4.03 & 4.16 & 0.13 & -0.66 & 2.01 & 2.67 & 3.37 & 6.17 & 2.80 \\
\hline United Kingdom & 2.68 & 2.04 & -0.64 & -0.72 & 0.37 & 1.09 & 1.96 & 2.41 & 0.45 \\
\hline Continental & 2.88 & 1.75 & -1.14 & -0.89 & -0.13 & 0.76 & 1.99 & 1.62 & -0.37 \\
\hline Austria & 3.12 & 2.28 & -0.85 & -0.66 & -0.18 & 0.48 & 2.46 & 2.09 & -0.37 \\
\hline Belgium & 2.85 & 1.42 & -1.43 & -0.68 & 0.50 & 1.17 & 2.17 & 1.92 & -0.25 \\
\hline France & 3.05 & 1.85 & -1.19 & -1.15 & -0.16 & 0.99 & 1.90 & 1.70 & -0.20 \\
\hline Germany & 2.91 & 1.67 & -1.23 & -0.96 & -0.33 & 0.63 & 1.94 & 1.34 & -0.60 \\
\hline Luxembourg & 2.50 & 1.92 & -0.58 & 0.29 & 1.28 & 0.99 & 2.78 & 3.20 & 0.41 \\
\hline Netherlands & 2.30 & 1.54 & -0.76 & -0.54 & 0.47 & 1.01 & 1.76 & 2.01 & 0.25 \\
\hline Portugal & 2.85 & 1.70 & -1.15 & 0.16 & 0.05 & -0.11 & 3.01 & 1.75 & -1.26 \\
\hline Mediterranean & 3.15 & 0.24 & -2.91 & -0.75 & 1.92 & 2.67 & 2.40 & 2.15 & -0.25 \\
\hline Greece & 2.36 & 2.53 & 0.17 & -0.33 & 1.13 & 1.46 & 2.03 & 3.66 & 1.63 \\
\hline Italy & 2.71 & 0.44 & -2.28 & -0.43 & 0.74 & 1.16 & 2.29 & 1.18 & -1.11 \\
\hline Spain & 4.19 & -0.24 & -4.43 & -1.35 & 3.69 & 5.04 & 2.84 & 3.46 & 0.61 \\
\hline Standard Deviation & 0.63 & 1.00 & & 0.46 & 1.02 & & 0.55 & 1.27 & \\
\hline
\end{tabular}




\begin{tabular}{|c|c|c|c|c|c|c|}
\hline \multicolumn{7}{|c|}{$\begin{array}{l}\text { Annual Growth Rates and Turnaround in Growth Rates of Labour Productivity, Labour and Capital Ratios, } \\
\text { and Total Factor Productivity, Countries and Country Groups, 1980-2004 }\end{array}$} \\
\hline & United States & EU-15 & Nordic & Anglo-Saxon & Continental & Mediterranean \\
\hline \multicolumn{7}{|l|}{ 1980-1995 Growth Rates } \\
\hline Labour Productivity $(\mathrm{Y} / \mathrm{H})$ & 1.34 & 2.34 & 2.30 & 2.46 & 2.46 & 2.07 \\
\hline Hours per Employee (H/E) & -0.13 & -0.49 & -0.02 & -0.16 & -0.77 & -0.32 \\
\hline Employent per Capita (E/N) & 0.51 & -0.04 & -0.74 & -0.23 & 0.03 & 0.11 \\
\hline Capital per Hour $(\mathrm{K} / \mathrm{H})$ & 3.56 & 3.68 & 4.06 & 4.44 & 3.47 & 3.52 \\
\hline Capital Deepening & 1.17 & 1.11 & 1.23 & 1.25 & 1.07 & 1.05 \\
\hline Total Factor Productivity (TFP) & 0.17 & 1.23 & 1.07 & 1.21 & 1.39 & 1.02 \\
\hline \multicolumn{7}{|l|}{ 1995-2004 Growth Rates } \\
\hline Labour Productivity $(\mathrm{Y} / \mathrm{H})$ & 2.29 & 1.41 & 1.92 & 2.11 & 1.63 & 0.63 \\
\hline Hours per Employee (H/E) & -0.16 & -0.39 & -0.16 & -0.37 & -0.57 & -0.29 \\
\hline Employent per Capita (E/N) & 0.06 & 0.92 & 0.56 & 1.01 & 0.49 & 1.73 \\
\hline Capital per Hour $(\mathrm{K} / \mathrm{H})$ & 3.56 & 2.81 & 2.86 & 3.99 & 2.99 & 2.01 \\
\hline Capital Deepening & 1.20 & 0.95 & 0.96 & 1.20 & 1.01 & 0.73 \\
\hline Total Factor Productivity (TFP) & 1.09 & 0.46 & 0.96 & 0.91 & 0.63 & -0.10 \\
\hline \multicolumn{7}{|c|}{ Difference, 1995-2004 minus 1980-1995 } \\
\hline Labour Productivity $(\mathrm{Y} / \mathrm{H})$ & 0.95 & -0.93 & -0.37 & -0.34 & -0.82 & -1.44 \\
\hline Hours per Employee (H/E) & -0.03 & 0.10 & -0.14 & -0.21 & 0.20 & 0.03 \\
\hline Employent per Capita (E/N) & -0.46 & 0.95 & 1.30 & 1.24 & 0.46 & 1.62 \\
\hline Capital per Hour (K/H) & -0.01 & -0.87 & -1.20 & -0.45 & -0.48 & -1.51 \\
\hline Capital Deepening & 0.03 & -0.16 & -0.27 & -0.05 & -0.06 & -0.32 \\
\hline Total Factor Productivity (TFP) & 0.92 & -0.77 & -0.11 & -0.29 & -0.76 & -1.12 \\
\hline \multicolumn{7}{|l|}{ Memo Items: } \\
\hline Capital-Output Ratio (K/Y) & -0.96 & 0.06 & -0.82 & -0.10 & 0.34 & -0.07 \\
\hline Capital per Capita $(\mathrm{K} / \mathrm{N})$ & -0.49 & 0.18 & -0.04 & 0.59 & 0.18 & 0.15 \\
\hline
\end{tabular}




\begin{tabular}{|c|c|c|c|}
\hline \multicolumn{4}{|c|}{$\begin{array}{l}\text { Regressions of Employment per Capita Growth } \\
\text { on Policy and Institutional Variables, 1980-2003 }\end{array}$} \\
\hline & Combined & Men & Women \\
\hline$\Delta$ Tax Wedge & $-0.28^{* * *}$ & $-0.21 * *$ & $-0.37 * \star \star$ \\
\hline$\Delta$ Employment Protection Legislation & 0.25 & 0.34 & -0.14 \\
\hline$\Delta$ Product Market Regulation & -0.55 & -0.29 & -0.75 \\
\hline$\Delta$ Average Replacement Rate & $-0.17^{* * *}$ & $-0.11^{* *}$ & $-0.27^{\star \star \star}$ \\
\hline$\Delta$ Union Density & $-0.47^{* * *}$ & $-0.41^{* * *}$ & $-0.56^{\star \star \star}$ \\
\hline$\Delta$ Output Gap & $0.51^{* * *}$ & $0.56^{* * *}$ & $0.46^{\star \star *}$ \\
\hline$\Delta$ High Corporatism & $-2.76^{* *}$ & $-1.87 *$ & $-4.20 * \star \star$ \\
\hline Post-1995 Dummy † & $0.95^{* * *}$ & $1.09^{* * *}$ & 0.66 *** \\
\hline \multicolumn{4}{|l|}{ Nordic } \\
\hline Denmark & -0.41 & -0.64 & -0.23 \\
\hline Finland & -0.43 & -0.69 & -0.23 \\
\hline Sweden & -0.88 * & $-1.12 * *$ & -0.56 \\
\hline \multicolumn{4}{|l|}{ Anglo-Saxon } \\
\hline Ireland & -0.33 & -1.16 & 1.38 \\
\hline United Kingdom & $-1.02 * \star *$ & $-1.45^{* * *}$ & -0.41 \\
\hline \multicolumn{4}{|l|}{ Continental } \\
\hline Austria & -0.30 & -0.87 & 0.50 \\
\hline Belgium & -0.16 & -0.76 & 0.82 \\
\hline France & $-0.57 * \star \star$ & $-1.16^{* * *}$ & 0.33 \\
\hline Germany & $-1.78 * \star \star$ & $-2.44^{* * *}$ & -0.86 ** \\
\hline Netherlands & 0.66 * & -0.30 & $2.46^{\star \star *}$ \\
\hline Portugal & -0.68 * & $-1.32 * * *$ & 0.33 \\
\hline \multicolumn{4}{|l|}{ Mediterranean } \\
\hline Greece & -0.14 & $-0.80 *$ & 1.09 ** \\
\hline Italy & -0.54 ** & $-1.06^{* * *}$ & $0.55^{*}$ \\
\hline Spain & 0.02 & $-0.77^{* * *}$ & 1.62 *** \\
\hline R2 & 0.47 & 0.47 & 0.37 \\
\hline $\mathbf{N}$ & 314 & 312 & 312 \\
\hline RMSE & 1.32 & 1.34 & 1.65 \\
\hline $\begin{array}{l}\text { * Indicates significance at } 10 \% \text { level, } \\
\dagger \text { Equal to } 1 \text { if within } 1996-2003 \text {, otherv } \\
\text { All regressions weighted by population }\end{array}$ & * $1 \%$ & & \\
\hline \multicolumn{4}{|c|}{ Source: New specifications and analysis based on data obtained from } \\
\hline
\end{tabular}




\begin{tabular}{|c|c|c|c|c|}
\hline \multicolumn{5}{|c|}{$\begin{array}{c}\text { First-Stage Regressions of Employment per Capita Growth on Policy } \\
\text { and Institutional Variables, 1980-2003 }\end{array}$} \\
\hline & (1) & (2) & (3) & (4) \\
\hline$\Delta$ Tax Wedge & $\begin{array}{l}-0.38^{* * *} \\
(0.08)\end{array}$ & $\begin{array}{l}-0.28^{* * *} \\
(0.07)\end{array}$ & $\begin{array}{l}-0.25^{* * *} \\
(0.07)\end{array}$ & $\begin{array}{l}-0.15^{* *} \\
(0.08)\end{array}$ \\
\hline$\Delta$ Employment Protection Legislation & $\begin{array}{l}-0.20 \\
(0.82)\end{array}$ & $\begin{array}{r}0.86 \\
(0.79)\end{array}$ & $\begin{array}{l}1.57 * \\
(0.87)\end{array}$ & $\begin{array}{r}0.27 \\
(0.83)\end{array}$ \\
\hline$\Delta$ Product Market Regulation & $\begin{array}{l}-1.11 * \\
(0.57)\end{array}$ & $\begin{array}{r}-0.44 \\
(0.55)\end{array}$ & $\begin{array}{r}0.66 \\
(0.62)\end{array}$ & $\begin{array}{r}-0.05 \\
(0.67)\end{array}$ \\
\hline$\Delta$ Average Replacement Rate & $\begin{array}{l}-0.21^{* * *} \\
(0.05)\end{array}$ & $\begin{array}{l}-0.18^{* * *} \\
(0.05)\end{array}$ & $\begin{array}{l}-0.13^{* *} \\
(0.05)\end{array}$ & $\begin{array}{l}-0.18^{* * *} \\
(0.05)\end{array}$ \\
\hline$\Delta$ Union Density & $\begin{array}{l}-0.43^{* * *} \\
(0.11)\end{array}$ & $\begin{array}{l}-0.46^{* * *} \\
(0.10)\end{array}$ & $\begin{array}{l}-0.45^{* * *} \\
(0.10)\end{array}$ & $\begin{array}{l}-0.41^{* * *} \\
(0.11)\end{array}$ \\
\hline$\Delta$ High Corporatism & $\begin{array}{l}-2.27^{* *} \\
(1.04)\end{array}$ & $\begin{array}{l}-2.04^{* *} \\
(0.98)\end{array}$ & $\begin{array}{l}-1.70 * \\
(0.86)\end{array}$ & $\begin{array}{l}-1.59 * \\
(0.96)\end{array}$ \\
\hline$\Delta$ Output Gap & $\begin{array}{l}0.54^{* * *} \\
(0.05)\end{array}$ & $\begin{array}{l}0.52^{* * *} \\
(0.05)\end{array}$ & $\begin{array}{l}0.51^{* * *} \\
(0.05)\end{array}$ & $\begin{array}{l}0.38^{* * *} \\
(0.06)\end{array}$ \\
\hline Post-1995 Dummy ${ }^{\dagger}$ & & $\begin{array}{l}0.94^{* * *} \\
(0.15)\end{array}$ & $\begin{array}{l}0.86^{* * *} \\
(0.17)\end{array}$ & $\begin{array}{l}1.15^{* * *} \\
(0.44)\end{array}$ \\
\hline R2 & 0.46 & 0.52 & 0.48 & 0.59 \\
\hline $\mathbf{N}$ & 320 & 320 & 320 & 320 \\
\hline RMSE & 1.25 & 1.18 & 1.31 & 1.09 \\
\hline $\begin{array}{l}\text { Weighted by Population } \\
\text { Year Dummies Included }\end{array}$ & $\begin{array}{l}\text { Yes } \\
\text { No }\end{array}$ & $\begin{array}{l}\text { Yes } \\
\text { No }\end{array}$ & $\begin{array}{l}\mathrm{No} \\
\mathrm{No}\end{array}$ & $\begin{array}{l}\text { Yes } \\
\text { Yes }\end{array}$ \\
\hline $\begin{array}{l}* \text { Indicates significance at } 10 \% \text { level, } * * 5 \%, * \\
\dagger \text { Equal to } 1 \text { if within } 1996-2003, \text { otherwise } 0 \\
\text { All regressions include country fixed effects } \\
\text { Source: Authors' Calculations }\end{array}$ & Time and fi & effects coe & ents not $\mathrm{r}$ & ted. \\
\hline
\end{tabular}




\begin{tabular}{|c|c|c|c|c|c|c|}
\hline \multicolumn{7}{|c|}{$\begin{array}{l}\text { Second-Stage Regressions of Productivity Growth on Employment per Capita } \\
\text { Growth and Policy and Institutional Variables, 1980-2003 }\end{array}$} \\
\hline & (1) & (2) & (3) & (4) & (5) & (6) \\
\hline Employment Rate & $\begin{array}{l}{ }^{-0.84^{* * *}} \\
(0.04)\end{array}$ & $\begin{array}{l}-0.64^{* * *} \\
(0.20)\end{array}$ & $\begin{array}{l}-0.74^{* * *} \\
(0.10)\end{array}$ & $\begin{array}{l}-0.64^{* * *} \\
(0.12)\end{array}$ & 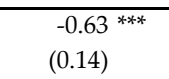 & $\begin{array}{l}-0.62^{* * *} \\
(0.16)\end{array}$ \\
\hline$\Delta$ Tax Wedge & $\begin{array}{r}-0.04 \\
(0.06)\end{array}$ & & & & & \\
\hline$\Delta$ Employment Protection Legislation & $\begin{array}{l}1.82^{* * *} \\
(0.62)\end{array}$ & $\begin{array}{l}1.66^{* * *} \\
(0.65)\end{array}$ & $\begin{array}{l}1.77^{* * *} \\
(0.60)\end{array}$ & $1.62 * *$ & $\begin{array}{r}1.07 \\
(0.81)\end{array}$ & $\begin{array}{l}1.19 * \\
(0.64)\end{array}$ \\
\hline$\Delta$ Product Market Regulation & $\begin{array}{r}0.48 \\
(0.43)\end{array}$ & $\begin{array}{r}0.56 \\
(0.45)\end{array}$ & $\begin{array}{r}0.54 \\
(0.44)\end{array}$ & $\begin{array}{r}0.58 \\
(0.44)\end{array}$ & $\begin{array}{l}0.98 \text { * } \\
(0.56)\end{array}$ & $\begin{array}{r}0.8 \\
(0.52)\end{array}$ \\
\hline$\Delta$ Average Replacement Rate & $\begin{array}{l}0.10^{* * *} \\
(0.04)\end{array}$ & $\begin{array}{l}0.14^{* * *} \\
(0.05)\end{array}$ & $\begin{array}{l}0.12^{* * *} \\
(0.04)\end{array}$ & $\begin{array}{l}0.13^{* * *} \\
(0.05)\end{array}$ & $\begin{array}{l}0.13 \text { ** } \\
(0.05)\end{array}$ & $\begin{array}{l}0.14^{* * *} \\
(0.05)\end{array}$ \\
\hline$\Delta$ Union Density & $\begin{array}{r}-0.06 \\
(0.08)\end{array}$ & $\begin{array}{r}0.03 \\
(0.12)\end{array}$ & $\begin{array}{l}-0.02 \\
(0.09)\end{array}$ & & & \\
\hline$\Delta$ High Corporatism & $\begin{array}{r}-0.94 \\
(0.77)\end{array}$ & $\begin{array}{r}-0.49 \\
(0.94)\end{array}$ & $\begin{array}{r}-0.73 \\
(0.82)\end{array}$ & & & \\
\hline$\Delta$ Output Gap & $\begin{array}{l}0.78^{* * *} \\
(0.04)\end{array}$ & $\begin{array}{l}0.68^{* * *} \\
(0.11)\end{array}$ & $\begin{array}{l}0.73^{* * *} \\
(0.07)\end{array}$ & $\begin{array}{l}0.67^{* * *} \\
(0.08)\end{array}$ & $\begin{array}{l}0.74^{* * *} \\
(0.09)\end{array}$ & $\begin{array}{l}0.76^{* * *} \\
(0.08)\end{array}$ \\
\hline Post-1995 Dummy ${ }^{\dagger}$ & $\begin{array}{r}0.06 \\
(0.13)\end{array}$ & $\begin{array}{l}-0.14 \\
(0.24)\end{array}$ & & $\begin{array}{r}-0.14 \\
(0.18)\end{array}$ & $\begin{array}{r}0.15 \\
(0.21)\end{array}$ & \\
\hline $\mathbf{R} 2$ & 0.65 & 0.63 & 0.64 & 0.62 & 0.52 & 0.69 \\
\hline $\mathbf{N}$ & 320 & 320 & 320 & 320 & 320 & 320 \\
\hline RMSE & 0.92 & 0.95 & 0.93 & 0.95 & 1.18 & 0.86 \\
\hline $\begin{array}{l}\text { Weighted by Population } \\
\text { Year Dummies Included }\end{array}$ & $\begin{array}{l}\text { Yes } \\
\text { No }\end{array}$ & $\begin{array}{l}\text { Yes } \\
\text { No }\end{array}$ & $\begin{array}{l}\text { Yes } \\
\text { No }\end{array}$ & $\begin{array}{l}\text { Yes } \\
\text { No }\end{array}$ & $\begin{array}{l}\text { No } \\
\text { No }\end{array}$ & $\begin{array}{l}\text { Yes } \\
\text { Yes }\end{array}$ \\
\hline Exogenous Instrument(s) & None & Tax wedge & $\begin{array}{r}\text { Tax wedge } \\
\text { Post-1995 TE }\end{array}$ & $\begin{array}{l}\text { Tax wedge } \\
\text { High Corp. } \\
\text { Union Dens. }\end{array}$ & $\begin{array}{l}\text { Tax wedge } \\
\text { High Corp. } \\
\text { Union Dens. }\end{array}$ & $\begin{array}{l}\text { Tax wedge } \\
\text { High Corp } \\
\text { Union Dens }\end{array}$ \\
\hline \multicolumn{7}{|c|}{$\begin{array}{l}\text { Indicates significance at } 10 \% \text { level, }{ }^{* *} 5 \%,{ }^{* *} 1 \% \text {. Year and country dummy coefficients not reported. } \\
\text { † Equal to } 1 \text { if within } 1996-2003 \text {, otherwise } 0 \\
\text { All regressions include country fixed effects } \\
\text { Source: Author's Calculations }\end{array}$} \\
\hline
\end{tabular}




\begin{tabular}{|c|c|c|c|c|c|c|c|c|c|}
\hline & ctual, Pre & ted, an & Counterfa & ctual Simul & $\begin{array}{l}\text { able } 6 \\
\text { ations of } \mathrm{Pr}\end{array}$ & vity and & mployme & nt Growth & \\
\hline & & \multicolumn{4}{|c|}{ Labor Productivity } & \multicolumn{4}{|c|}{ Employment per Capita } \\
\hline & & Actual & Predicted & Fixed Policy & Policy Effect & Actual & Predicted & Fixed Policy & Policy Effect \\
\hline \multirow{3}{*}{ Mediterranean } & Pre-95 & 2.53 & 2.12 & 1.82 & 0.30 & -0.27 & 0.06 & 0.35 & -0.29 \\
\hline & Post-95 & 0.52 & 0.90 & 1.18 & -0.28 & 1.87 & 1.63 & 1.46 & 0.17 \\
\hline & Change & -2.01 & -1.23 & -0.65 & -0.58 & 2.14 & 1.57 & 1.11 & 0.46 \\
\hline \multirow{3}{*}{ Continental } & Pre-95 & 2.26 & 2.38 & 2.41 & -0.03 & -0.04 & -0.12 & -0.28 & 0.16 \\
\hline & Post-95 & 1.76 & 1.57 & 1.75 & -0.18 & 0.76 & 0.92 & 0.80 & 0.12 \\
\hline & Change & -0.50 & -0.81 & -0.66 & -0.15 & 0.80 & 1.04 & 1.08 & -0.04 \\
\hline \multirow{3}{*}{ Nordic } & Pre-95 & 2.00 & 2.33 & 2.27 & 0.06 & -0.61 & -0.80 & -0.64 & -0.17 \\
\hline & Post-95 & 1.92 & 1.38 & 1.80 & -0.41 & 0.70 & 1.02 & 0.73 & 0.29 \\
\hline & Change & -0.08 & -0.95 & -0.47 & -0.47 & 1.31 & 1.82 & 1.36 & 0.46 \\
\hline \multirow{3}{*}{ Anglo-Saxon } & Pre-95 & 2.52 & 2.56 & 3.14 & -0.57 & -0.23 & -0.25 & -0.92 & 0.67 \\
\hline & Post-95 & 2.23 & 2.13 & 2.57 & -0.44 & 0.83 & 0.86 & 0.26 & 0.60 \\
\hline & Change & -0.29 & -0.43 & -0.57 & 0.13 & 1.06 & 1.12 & 1.18 & -0.07 \\
\hline \multirow{3}{*}{ EU-15 } & Pre-95 & 2.32 & 2.33 & 2.39 & -0.06 & -0.15 & -0.15 & -0.28 & 0.13 \\
\hline & Post-95 & 1.44 & 1.44 & 1.73 & -0.29 & 1.16 & 1.16 & 0.91 & 0.25 \\
\hline & Change & -0.88 & -0.89 & -0.66 & -0.23 & 1.31 & 1.31 & 1.19 & 0.12 \\
\hline
\end{tabular}




\begin{tabular}{|c|c|c|c|c|}
\hline \multicolumn{5}{|c|}{$\begin{array}{c}\text { Effects of Unit Standard Deviation Policy Shocks on Employment } \\
\text { Productivity, and Output per Capita }\end{array}$} \\
\hline & Shock Size & Employment & Productivity & Output Per Capita \\
\hline Tax Wedge & 9.21 & $\begin{array}{l}-2.67^{* * *} \\
(0.64)\end{array}$ & $\begin{array}{l}1.71^{* * *} \\
(0.53)\end{array}$ & $\begin{array}{l}-0.96 * * \\
(0.4)\end{array}$ \\
\hline $\begin{array}{l}\text { Employment } \\
\text { Protection Legislation }\end{array}$ & 0.87 & $\begin{array}{l}0.74^{* *} \\
(0.36)\end{array}$ & $\begin{array}{r}0.23 \\
(0.37)\end{array}$ & $\begin{array}{l}0.97^{\star * *} \\
(0.31)\end{array}$ \\
\hline Product Market Regulation & 0.9 & $\begin{array}{r}-0.14 \\
(0.24)\end{array}$ & $\begin{array}{r}0.35 \\
(0.25)\end{array}$ & $\begin{array}{r}0.21 \\
(0.22)\end{array}$ \\
\hline Average Replacement Rate & 11.31 & $\begin{array}{l}-0.90^{* * *} \\
(0.34)\end{array}$ & $\begin{array}{l}1.37^{* * *} \\
(0.31)\end{array}$ & $\begin{array}{c}0.47 \text { * } \\
(0.25)\end{array}$ \\
\hline Union Density & 23.32 & $\begin{array}{l}-7.93^{* * *} \\
(1.17)\end{array}$ & $\begin{array}{l}5.07^{* * *} \\
(1.23)\end{array}$ & $\begin{array}{l}-2.85 \text { *** } \\
(1.07)\end{array}$ \\
\hline High Corpratism & 1 & $\begin{array}{l}-1.02^{* *} \\
(0.48)\end{array}$ & $\begin{array}{l}0.65^{* *} \\
(0.33)\end{array}$ & $\begin{array}{l}-0.37 \text { * } \\
(0.21)\end{array}$ \\
\hline \multicolumn{5}{|c|}{ Note: Standard errors (Delta method) in parenthes } \\
\hline
\end{tabular}




\begin{tabular}{|c|c|c|c|c|}
\hline \multicolumn{5}{|c|}{ Table A1 } \\
\hline \multicolumn{5}{|c|}{ First-Stage Regressions of Employment on Policy Variables, 1980-2003 } \\
\hline & 1 & 2 & 3 & 4 \\
\hline Tax Wedge & $\begin{array}{l}-0.25^{* * *} \\
(0.06)\end{array}$ & $\begin{array}{l}-0.25^{* * *} \\
(0.07)\end{array}$ & $\begin{array}{l}-0.2^{* * *} \\
(0.07)\end{array}$ & $\begin{array}{l}-0.14^{*} \\
(0.07)\end{array}$ \\
\hline $\begin{array}{l}\text { Employment } \\
\text { Protection Legislation }\end{array}$ & $\begin{array}{r}0.88 \\
(0.75)\end{array}$ & $\begin{array}{r}1.38 \\
(0.86)\end{array}$ & $\begin{array}{r}0.90 \\
(0.30)\end{array}$ & $\begin{array}{l}-1.03 \\
(0.79)\end{array}$ \\
\hline $\begin{array}{l}\text { Product Market } \\
\text { Regulation }\end{array}$ & $\begin{array}{r}0.24 \\
(0.49)\end{array}$ & $\begin{array}{r}0.34 \\
(0.51)\end{array}$ & $\begin{array}{l}-0.99 * * \\
(0.48)\end{array}$ & $\begin{array}{r}-0.84 \\
(0.56)\end{array}$ \\
\hline $\begin{array}{l}\text { Unemployment } \\
\text { Benefits (ARR) }\end{array}$ & $\begin{array}{l}-0.08 * \\
(0.05)\end{array}$ & $\begin{array}{r}-0.01 \\
(0.06)\end{array}$ & $\begin{array}{l}-0.19^{* * *} \\
(0.05)\end{array}$ & $\begin{array}{l}-0.21^{* * *} \\
(0.05)\end{array}$ \\
\hline Union Density & $\begin{array}{l}-0.29^{* * *} \\
(0.10)\end{array}$ & $\begin{array}{l}-0.35^{* * *} \\
(0.11)\end{array}$ & $\begin{array}{l}-0.49^{* * *} \\
(0.10)\end{array}$ & $\begin{array}{l}-0.44^{* * *} \\
(0.10)\end{array}$ \\
\hline High Corpratism Dummy & $\begin{array}{l}-2.95^{* * *} \\
(0.83)\end{array}$ & $\begin{array}{l}-2.32 * \\
(1.22)\end{array}$ & $\begin{array}{l}-2.18^{* *} \\
(1.02)\end{array}$ & $\begin{array}{l}-2.04 * * \\
(0.97)\end{array}$ \\
\hline Output Gap & $\begin{array}{l}0.46^{* * *} \\
(0.04)\end{array}$ & $\begin{array}{l}0.55^{* * *} \\
(0.04)\end{array}$ & $\begin{array}{l}0.54^{* * *} \\
(0.03)\end{array}$ & $\begin{array}{l}0.64^{* * *} \\
(0.05)\end{array}$ \\
\hline Post-1995 Dummy & $\begin{array}{l}0.66^{* * *} \\
(0.14)\end{array}$ & $\begin{array}{l}0.75^{* * *} \\
(0.14)\end{array}$ & $\begin{array}{r}0.93 \\
(0.16)\end{array}$ & $\begin{array}{l}0.91^{* * *} \\
(0.16)\end{array}$ \\
\hline Post-'95 Dummy (U.S.) & & & $\begin{array}{l}-0.38^{* *} \\
(0.17)\end{array}$ & \\
\hline R2 & 0.48 & 0.53 & 0.58 & 0.53 \\
\hline RMSE & 1.02 & 0.99 & 0.96 & 1.15 \\
\hline $\mathbf{N}$ & 296 & 251 & 344 & 306 \\
\hline Notes & Spain Excluded & $\begin{array}{l}\text { Mediterranean Countries } \\
\text { Excluded }\end{array}$ & $\begin{array}{l}\text { U.S. included, with a } \\
\text { separate post-'95 dummy }\end{array}$ & $\begin{array}{l}\text { All explanatory } \\
\text { variables except } \\
\text { output gap lagged } \\
\text { by one year }\end{array}$ \\
\hline \multicolumn{5}{|c|}{ All regressions include population weights and fixed country dummies } \\
\hline Source: Authors' Calculations & & & & \\
\hline
\end{tabular}


Table A2

Second-Stage Regressions of Productivity on Employment and Policy Variables

\begin{tabular}{|c|c|c|c|c|c|c|c|}
\hline & 1 & 2 & 3 & 4 & & 5 & 6 \\
\hline Employment Rate & $\begin{array}{l}-0.56^{* *} \\
(0.26)\end{array}$ & $\begin{array}{l}-0.46^{* *} \\
(0.22)\end{array}$ & $\begin{array}{l}-0.24 \\
(0.23)\end{array}$ & 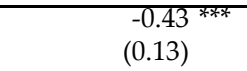 & 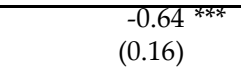 & $\begin{array}{r}-0.39 \\
(0.31)\end{array}$ & 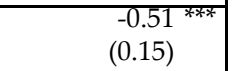 \\
\hline Tax Wedge & & & & & $\begin{array}{r}0.01 \\
(0.04)\end{array}$ & & \\
\hline $\begin{array}{l}\text { Employment } \\
\text { Protection Legislation }\end{array}$ & $\begin{array}{r}1.05 \\
(0.94)\end{array}$ & $\begin{array}{l}1.88^{* *} \\
(0.92)\end{array}$ & $\begin{array}{l}2.43^{* * *} \\
(0.90)\end{array}$ & $\begin{array}{l}2.72^{* * *} \\
(0.86)\end{array}$ & ${ }^{1.6^{* *}}$ & $\begin{array}{l}1.49 * \\
(0.82)\end{array}$ & $\begin{array}{l}1.56^{* *} \\
(0.76)\end{array}$ \\
\hline $\begin{array}{l}\text { Product Market } \\
\text { Regulation }\end{array}$ & $\begin{array}{r}0.27 \\
(0.50)\end{array}$ & $\begin{array}{r}-0.56 \\
(0.63)\end{array}$ & $\begin{array}{r}0.93 \\
(0.68)\end{array}$ & $\begin{array}{r}0.65 \\
(0.63)\end{array}$ & $\begin{array}{r}0.59 \\
(0.44)\end{array}$ & $\begin{array}{r}0.47 \\
(0.50)\end{array}$ & $\begin{array}{r}0.4 \\
(0.44)\end{array}$ \\
\hline $\begin{array}{l}\text { Unemployment } \\
\text { Benefits (ARR) }\end{array}$ & $\begin{array}{l}0.25^{* * *} \\
(0.06)\end{array}$ & $\begin{array}{l}0.15^{* *} \\
(0.07)\end{array}$ & $\begin{array}{l}0.17^{* *} \\
(0.07)\end{array}$ & $\begin{array}{l}0.14^{* *} \\
(0.06)\end{array}$ & $\begin{array}{l}0.13^{* *} \\
(0.05)\end{array}$ & $\begin{array}{l}0.16^{* *} \\
(0.08)\end{array}$ & $\begin{array}{l}0.14^{* *} \\
(0.05)\end{array}$ \\
\hline Union Density & $\begin{array}{r}0.05 \\
(0.14)\end{array}$ & $\begin{array}{r}-0.16 \\
(0.18)\end{array}$ & $\begin{array}{r}0.14 \\
(0.18)\end{array}$ & & & $\begin{array}{r}0.08 \\
(0.17)\end{array}$ & \\
\hline Output Gap & $\begin{array}{l}0.65^{* * *} \\
(0.15)\end{array}$ & & $\begin{array}{l}0.28^{* * *} \\
(0.07)\end{array}$ & $\begin{array}{l}0.31^{* * *} \\
(0.06)^{*}\end{array}$ & $\begin{array}{l}0.67^{* * *} \\
(0.10)\end{array}$ & $\begin{array}{l}0.49^{* * *} \\
(0.17)\end{array}$ & $\begin{array}{l}0.56^{* * *} \\
(0.09)\end{array}$ \\
\hline High Corpratism Dummy & $\begin{array}{r}1.23 \\
(1.37)\end{array}$ & $\begin{array}{r}-0.57 \\
(1.30)\end{array}$ & $\begin{array}{r}1.37 \\
(1.31)\end{array}$ & & $\begin{array}{r}-0.25 \\
(0.21)\end{array}$ & $\begin{array}{r}0.24 \\
(1.24)\end{array}$ & \\
\hline Post-1995 Dummy & $\begin{array}{r}-0.06 \\
(0.27)\end{array}$ & $\begin{array}{r}0.20 \\
(0.28)\end{array}$ & $\begin{array}{r}-0.36 \\
(0.33)\end{array}$ & $\begin{array}{r}-0.13 \\
(0.24)\end{array}$ & $\begin{array}{r}-0.13 \\
(0.19)\end{array}$ & $\begin{array}{r}-0.41 \\
(0.36)\end{array}$ & $\begin{array}{r}-0.28 \\
(0.21)\end{array}$ \\
\hline Post-'95 Dummy (U.S.) & & & & & & $\begin{array}{l}0.46^{* * *} \\
(0.17)\end{array}$ & $\begin{array}{l}0.44^{* * *} \\
(0.15)\end{array}$ \\
\hline R2 & 0.51 & 0.27 & 0.31 & 0.30 & 0.63 & 0.51 & 0.56 \\
\hline RMSE & 0.97 & 1.3 & 1.28 & 1.28 & 0.95 & 0.93 & 0.88 \\
\hline $\mathbf{N}$ & 251 & 329 & 305 & 305 & 320 & 344 & 344 \\
\hline Exogenous Instruments & Tax Wedge & Tax Wedge & Tax Wedge & $\begin{array}{l}\text { Tax Wedge } \\
\text { High Corp. } \\
\text { Unions }\end{array}$ & $\begin{array}{l}\text { High Corp. } \\
\text { Unions }\end{array}$ & Tax Wedge & $\begin{array}{l}\text { Tax Wedge } \\
\text { High Corp. } \\
\text { Unions }\end{array}$ \\
\hline Notes & $\begin{array}{l}\text { Mediterranean Countries } \\
\text { Excluded }\end{array}$ & $\begin{array}{l}\text { Output Gap } \\
\text { Excluded }\end{array}$ & $\begin{array}{l}\text { All explanatory } \\
\text { variables except } \\
\text { output gap lagged } \\
\text { by one year }\end{array}$ & $\begin{array}{l}\text { All explanatory } \\
\text { variables except } \\
\text { output gap lagged } \\
\text { by one year }\end{array}$ & $\begin{array}{l}\text { Tax wedge not } \\
\text { used as an } \\
\text { exogenous } \\
\text { instrument }\end{array}$ & $\begin{array}{l}\text { U.S. included, } \\
\text { with a separate } \\
\text { post-'95 dummy }\end{array}$ & $\begin{array}{l}\text { U.S. included, } \\
\text { with a separate } \\
\text { post-'95 dummy }\end{array}$ \\
\hline
\end{tabular}

